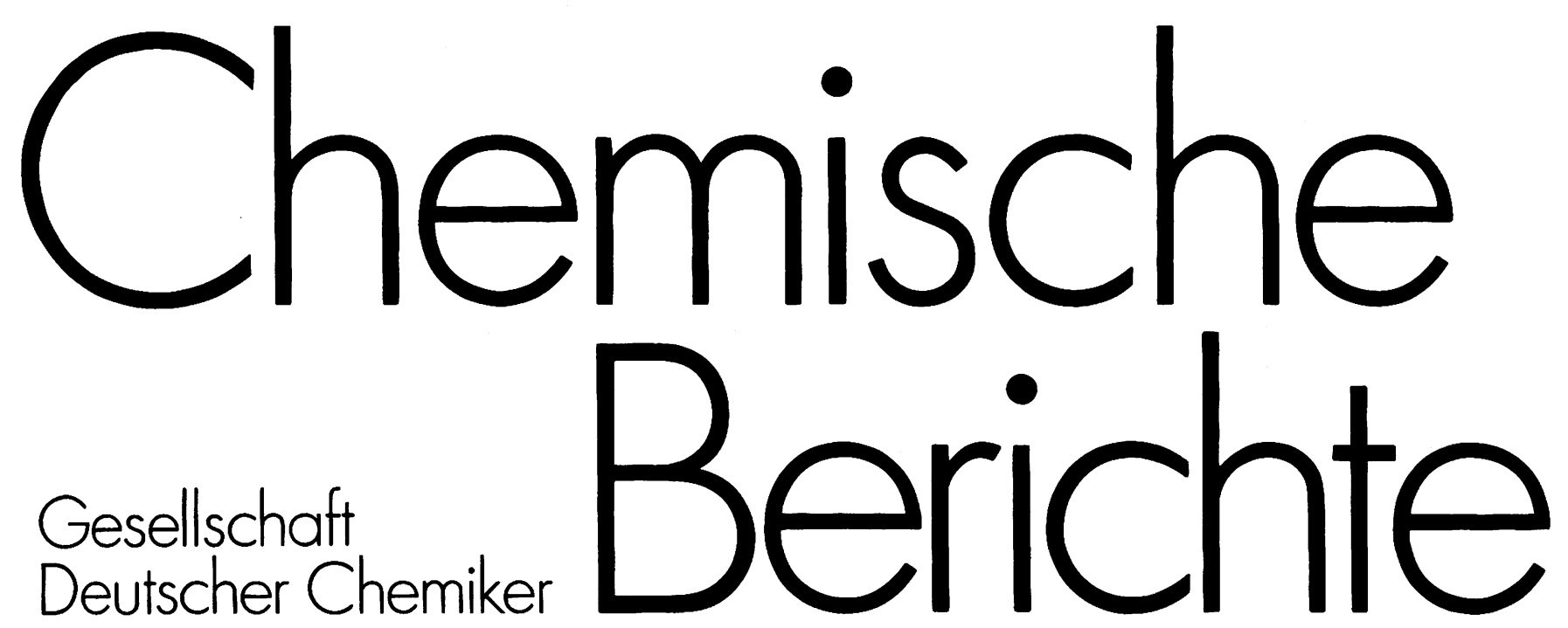

Founded 1868

December 1994 - Volume 127 - Issue 12 - Pages 2353-2542 - Index 2543-2568

$\begin{array}{lll}\text { Editorial Board: } & \text { Wolfgang Beck } & \text { Martin Jansen } \\ & \text { Rolf Gleiter } & \text { Klaus Müllen } \\ & \text { Klaus Hafner } & \text { Heinrich Nöth } \\ & \text { Henning Hopf } & \text { Werner Schroth }\end{array}$

Helmut Schwarz

Werner Tochtermann

Heinrich Vahrenkamp

$\begin{array}{llll}\text { Managing Editor: } & \text { Robert Temme } & \text { Administration: } & \text { Hannelore Holm } \\ \text { Associate Editors: } & \text { Udo Eberhardt } & \text { Production: } & \text { Olga Olivecká }\end{array}$

Editorial Office: Chemische Berichte

P.O. Box 101161

D-69451 Weinheim

Federal Republic of Germany

Telephone (internat.) +49 6201 606-255

Telefax (internat.) +49 6201 606-328
Publisher:

\begin{tabular}{|c|c|}
\hline VCH Verlagsgesells & haft mbH \\
\hline P.O. Box 101161 & \\
\hline D-69451 Weinheim & \\
\hline Federal Republic of & Germany \\
\hline Telephone (internat.) & $+496201606-0$ \\
\hline Telefax (internat.) & $+496201606-328$ \\
\hline Telex & 465516 vchwh d \\
\hline
\end{tabular}

Die Chemischen Berichte erscheinen monatlich. Die Bezugsbedingungen für Mitglieder der Gesellschaft Deutscher Chemiker werden auf Anfrage von der Geschäftsstelle, Carl-Bosch-Haus, Varrentrappstraße 40-42, Postfach 900440, D-60444 Frankfurt, mitgeteilt. Bestellungen richten Sie bitte an Ihre Fachbuchhandlung oder unmittelbar an den Verlag. Abbestellungen nur bis spätestens 3 Monate vor Ablauf des Kalenderjahres. Die Lieferung erfolgt auf Rechnung und Gefahr des Empfängers. Gerichtsstand und Erfüllungsort: Weinheim.

Subscription rates (1995) including postage and handling (for additional information see editorial inserted in issue 9):

Annual subscription: DM 1300.- (Germany), ÖS 10374.- (Austria), SFr 1300. - (Switzerland), GB£ 583. - (Great Britain), US\$ 887.- (USA), DM 1330. - (elsewhere); single issue: DM 128. - (Germany; elsewhere on request).

Back volumes of Chemische Berichte are available on microfilm (further information and prices on request).
For the USA and Canada: Chemische Berichte (ISSN 0009-2940) is published monthly by VCH Publishers, Inc., 303 N.W. 12th Avenue, Deerfield Beach FL 33442-1788; Telefax (305) 428-8201; Telephone (305) 428-5566 or (800) 4228824. Second-class postage paid at Deerfield Beach FL 33441. Annual subscription price: US $\$ 1030.00$, single issue: US $\$ 107.00$ including postage and handling charges. Reduced rate for individual members of the American Chemical Society on request. - Printed in the Federal Republic of Germany.

U.S. POSTMASTER: Send address changes to Chemische Berichte, c/o VCH Publishers, Inc., 303 N.W. 12th Avenue, Deerfield Beach FL 33442-1788.

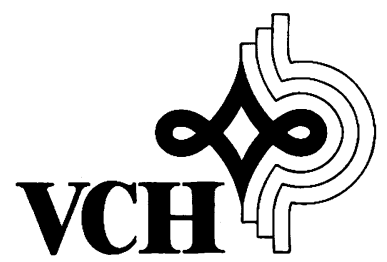


Albrecht, K., 2539

Angermaier, K., 2387

Angstl, M., 2373

Aumann, R., 2475

Beckmann, M., 2505

Bekaroğlu, Ö., 2483

Berke, H., 2403

Bosch, H. W., 2403

Davidson, M. G., 2489

de Meijere, A., 2539

Dunsch, L., 2423

Engelking, H., 2355

Feßenbecker, A., 2393

Fritz, H., 2435

Gangnus, B., 2393

Glanz, M., 2363, 2369

Gollas, B., 2423

Hamuryudan, E., 2483

Hartmann, U., 2381
Hemling, H., 2363, 2369

Hoffmann, R. W., 2511, 2519

Jamrozik, J., 2471

Jany, G., 2417

Jasper, B., 2475

Karentzopoulos, S., 2355

Keller, M., 2435

Kratz, T., 2369

Krebs, B., 2355, 2475

Kuhn, N., 2369

Kümmerlin, M., 2431

Läge, M., 2475

Lüning, U., 2431

Maier, G., 2527, 2531

Mayr, H., 2493

Meyer, T., 2505

Mloston, G., 2527

Nehl, H., 2535

Neudeck, A., 2423
Niecke, E., 2397

Nieger, M., 2397

Nietlispach, D., 2403

Oberdörfer, R., 2397

Petr, A., 2423

Priermeier, T., 2373

Pritzkow, H., 2393

Rau, D., 2493

Reisenauer, H. P., 2527

Reusmann, G., 2355

Rieger, B., 2417

Romanski, J., 2527

Saalfrank, R. W., 2489

Schlemper, H., 2435

Schmidbaur, H., 2387

Schmidt, C., 2527

Schmitt, D., 2435

Schneider, H.-J., 2455

Schneider, U., 2455
Schulz, F., 2505

Schumann, H., 2363, 2369

Schwarz, H., 2499

Schwesinger, R., 2435

Siebert, W., 2393

Snaith, R., 2489

Speiser, B., 2423

Stahl, H., 2423

Stöckigt, D., 2499

Struck, O., 2489

Stürmer, R., 2511, 2519

Thiel, W. R., 2373

Vahrenkamp, H., 2381

Wangnick, C., 2431

Weber, C., 2531

Willaredt, J., 2435

Wintefeldt, E., 2505

Winterfeld, J., 2369

Żeslawski, W., 2471

\section{Allgemeine Hinweise}

1. Die Chemischen Berichte (zu zitieren als Chem. Ber) setzen seit 1946 die Berichte der Deutschen Chemischen Gesellschaft (zu zitieren als Ber. Dtsch. Chem. Ges.) fort. Die „Berichte“ enthalten Arbeiten aus dem Bereich der Anorganischen und Elementorganischen Chemie (Teil A) sowie der Organischen und Physikalisch-Organischen Chemie (Teil B). Bei der Organischen Chemie liegt der Schwerpunkt auf allgemeinen synthetischen Methoden und mechanistischen Problemen.

2. Die „Berichte“ erscheinen monatlich; ein Register beschließt jeden Jahrgang.

3. Die Verantwortung für ihre Mitteilungen tragen die Verfasser selbst. - Der Korrespondenzautor ist durch einen hochgestellten Stern hervorgehoben. Die Zugehörigkeit der Autoren zu den Instituten ist durch hochgestellte Kleinbuchstaben markiert.

4. Es werden grundsätzlich nur Arbeiten aufgenommen, die vorher weder im Inland noch im Ausland veröffentlicht worden sind.

5. Eine Anweisung zur Abfassung von Manuskripten fïr die „Berichte“ wird auf Wunsch zugestellt (siehe auch Heft $1, \mathbf{S}$. AI)

6. Manuskripte (in dreifacher Ausfertigung) sind zu senden an Redaktion der Chemischen Berichte, Dr. R. Temme, Postfach 101161, D-69451 Weinheim; Telefon (06201) 606-255.

7. Der Eingang der Abhandlungen wird den Autoren am Tage der Registrierung angezeigt.

8. Autoren werden gebeten, Manuskripte in englischer Sprache einzureichen. Allen Beiträgen ist eine knappe Zusammenfassung in Englisch voranzustellen.

9. Der Autor muß das alleinige Urheberrecht besitzen. Mit der Annahme des Manuskriptes durch die Redaktion überträgt er der VCH Verlagsgesellschaft das ausschließliche Nutzungsrecht, insbesondere das Recht der Vervielfältigung wie Fotokopie, Mikrofilm - oder mit irgendeinem anderen Verfahren - oder das Manuskript in eine von Maschinen, insbesondere von Datenverarbeitungsmaschinen, verwendbare Sprache zu übergeben oder zu übersetzen (auch in fremde Sprachen).

10. Den Autoren werden 25 Sonderdrucke unentgeltlich portofrei zugesandt. Wünscht ein Autor mehr als 25 Abzüge, so ist dies auf dem Manuskript oder spätestens bei Rücksendung der Korrektur auf dieser zu vermerken. Den Autoren werden nur die Selbstkosten für die Zahl der die Freiexemplare überschreitenden Sonderabzüge berechnet.

11. Anfragen nach dem Verbleib nicht eingetroffener Berichte-Hefte oder Sonderdrucke sind $\mathrm{zu}$ richten an: VCH Verlagsgesellschaft $\mathrm{mbH}$, Postfach 101161, D-69451 Weinheim, Telefon (06201) 606-0.

\section{General Remarks}

1. Chemische Berichte (abbreviated Chem Ber.; until 1946 Berichte der Deutschen Chemischen Gesellschaft, abbreviated Ber. Dtsch. Chem. Ges.) publishes articles on studies in inorganic and organometallic chemistry (Part A) as well as in organic and physical organic chemistry (Part B). In organic chemistry, emphasis is given to general synthetic methods and mechanistic problems.

2. Chemische Berichte is published monthly; the annual volume concludes with a List of Authors and a List of Contents.

3. Authors are solely responsible for their contributions. - The author to whom correspondence should be addressed should be indicated by an asterisk. Different addresses of coauthors should be given in lower-case letters.

4. The contents of a manuscript submitted to Chemische Berichte should not have been published previously, nor submitted to any other joumal, except in the form of brief preliminary communication.

5. For the preparation of manuscripts, a copy of the "Instructions for Authors" is available on request (see also issue 1, p. AI).

6. Manuscripts should be submitted in triplicate to: Redaktion Chemische Berichte, Dr. R. Temme, P.O. Box 101161, D-69451 Weinheim (FRG); Telephone (internat.) $+496201606-255$.

7. Acknowledgement of receipt of the manuscript will be confirmed on the day of registration.

8. Authors are asked to submit manuscripts in English. All contributions must be accompanied by a summary in English.

9. It is assumed that the authors concerned have the necessary authority for publication. Upon acceptance for publication, VCH Verlagsgesellschaft acquires all publishing rights including those of reprinting, translating or reproducing and distributing the manuscript in other forms (e.g. as photocopy, microfilm or in machine-readable form). Moreover, the provisions of the copyright law of the Federal Republic of Germany apply.

10. The author will receive one copy of the galley proofs, together with the edited manuscript and a reprint order form; the author will receive 25 reprints free of charge and may order additional copies at cost price.

11. All inquiries concerning journals or reprints should be addressed to: $\mathrm{VCH}$ Verlagsgesellschaft mbH, P.O. Box 101161, D-69451 Weinheim (FRG) Telephone (internat.) +49 6201 606-0. 


\section{A Teil A: Anorganische und elementorganische Chemie / Part A: Inorganic and Organometallic Chemistry}

Engelking, H., Karentzopoulos, S., Reusmann, G., Krebs*, B.

Neue dinucleare Palladium(II)-Komplexe mit dem Chelat-Liganden Bis(1-methylimidazol-2-yl)keton (bmik) und Pyridin-2-thiolat, Pyrimidin-2-thiolat und 1-Methylimidazol-2-thiolat als verbrückenden sekundären Liganden

Novel Dinuclear Palladium(II) Complexes with the Chelating Ligand Bis(1-methylimidazol-2-yl) Ketone (bmik) and Pyridine-2-thiolate, Pyrimidine-2-thiolate, and 1-Methylimidazole-2-thiolate as Bridging Secondary Ligands

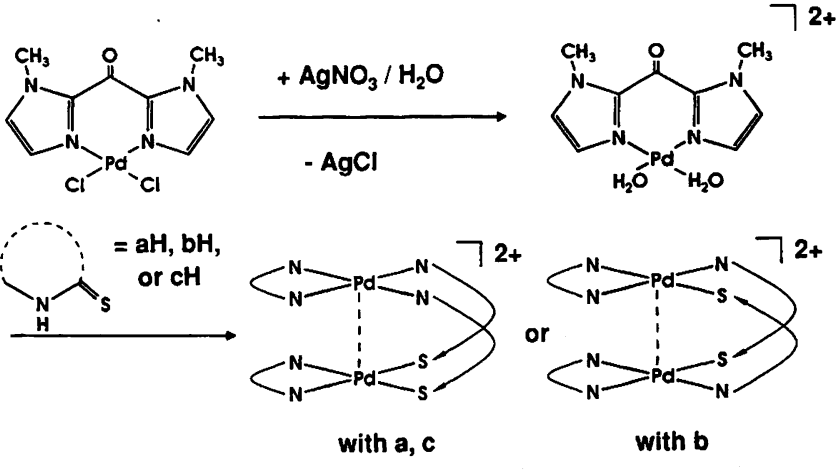

$a=\mathrm{C}_{5} \mathrm{H}_{4} \mathrm{NS}, \mathrm{b}=\mathrm{C}_{4} \mathrm{H}_{3} \mathrm{~N}_{2} \mathrm{~S}, \mathrm{c}=\mathrm{C}_{4} \mathrm{H}_{5} \mathrm{~N}_{2} \mathrm{~S}$
Schumann*, H., Glanz, M., Hemling, H.

Metallorganische Verbindungen der Lanthanoide, 90. - [(tert-Butylcyclopentadienyl)dimethyl(tetramethylcyclopentadienyl)silan]-Komplexe von Lanthan, Neodym und Lutetium

Organometallic Compounds of the Lanthanides, 90. [(tert-Butylcyclopentadienyl)dimethyl-(tetramethylcyclopentadienyl)silane] Complexes of Lanthanum, Neodymium, and Lutetium

2369 Schumann*, H., Glanz, M., Winterfeld, J., Hemling, H., Kuhn*, N., Kratz, T.

Metallorganische Verbindungen der Lanthanoide, 91.

- Carben-Addukte des zweiwertigen Samariums und Ytterbiums

Organometallic Compounds of the Lanthanides, 91. Carbene Complexes of Divalent Samarium and Ytterbium
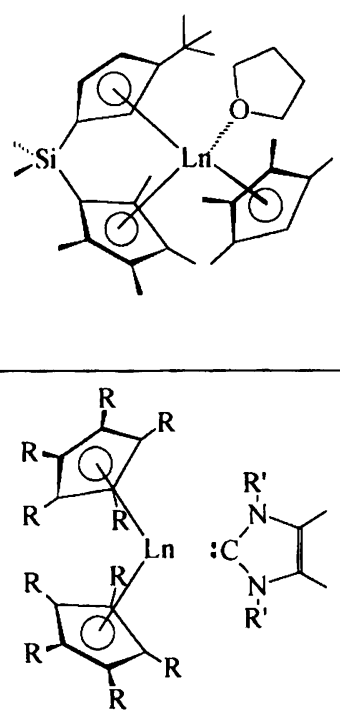

Thiel*, W. R., Angstl, M., Priermeier, T.

Substituierte N,N-Chelat-Liganden - Anwendungen in der Molybdän-katalysierten Olefin-Epoxidation

Substituted N,N-Chelate Ligands - Applications in Molybdenum-Catalyzed Epoxidation of Olefins
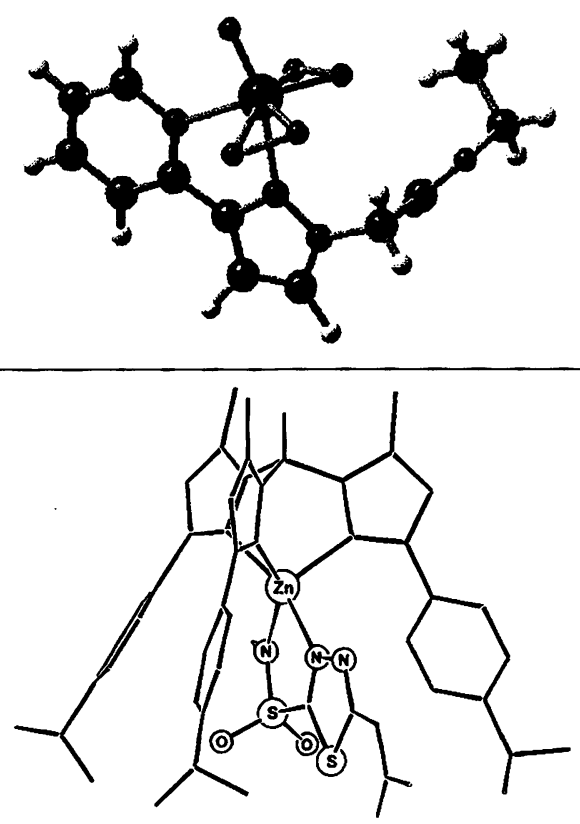
Die supramolekularen Strukturen von komplexen Tri[gold(I)]sulfonium-Kationen

The Supramolecular Structures of Complex Tri[gold-

(I)]sulfonium Cations

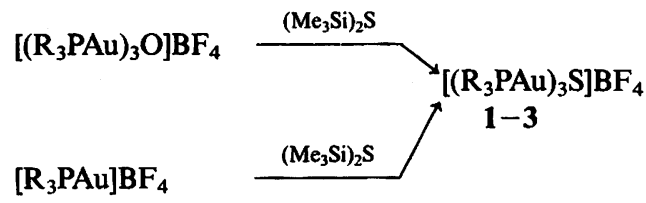

Gangnus, B., Feßenbecker, A., Pritzkow, H., Siebert*, W.

Komplexierung von 1,4-Dihydro-1,4-diborafulvenen mit Ni(cod)- und Pt(cod)-Fragmenten

Complexation of 1,4-Dihydro-1,4-diborafulvenes with $\mathrm{Ni}(\mathrm{cod})$ and Pt(cod) Fragments

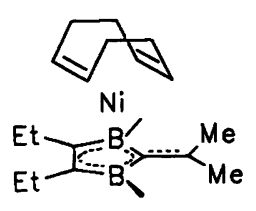

8
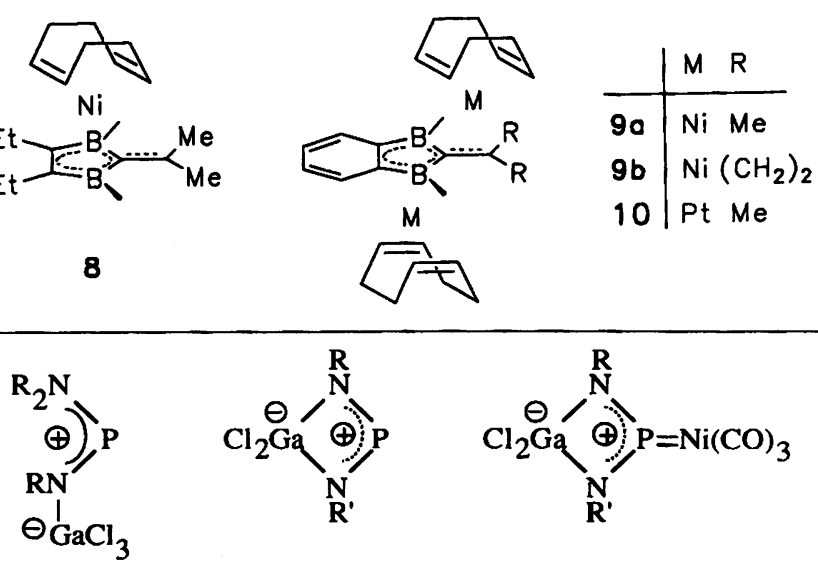

2397

Oberdörfer, R., Nieger, M., Niecke*, E.

1,3-Diaza-2 $\lambda^{2}$-phosphonia-4 $\lambda^{4}$-gallatacyclobutane

1,3-Diaza-2 $\lambda^{2}$-phosphonia-4 $\lambda^{4}$-gallatacyclobutanes

$\left(\mathrm{R}=\mathrm{SiMe}_{3}, \mathrm{R}^{\prime}=\mathrm{tBu}\right)$

Nietlispach, D., Bosch, H. W., Berke*, H.

Vergleich der Reaktivität von $\mathrm{Mn}(\mathrm{NO})_{2} \mathrm{~L}_{2} \mathrm{H}$ - und $\mathrm{Mn}(\mathrm{CO})_{3} \mathrm{~L}_{2} \mathrm{H}$-Komplexen ( $\mathrm{L}=$ Phosphordonor)

A Comparative Study of the Reactivity of $\mathrm{Mn}(\mathrm{NO})_{2} \mathrm{~L}_{2} \mathrm{H}$ and $\mathrm{Mn}(\mathrm{CO})_{3} \mathrm{~L}_{2} \mathrm{H}$ Complexes $(\mathrm{L}=$ Phosphorus Donor)
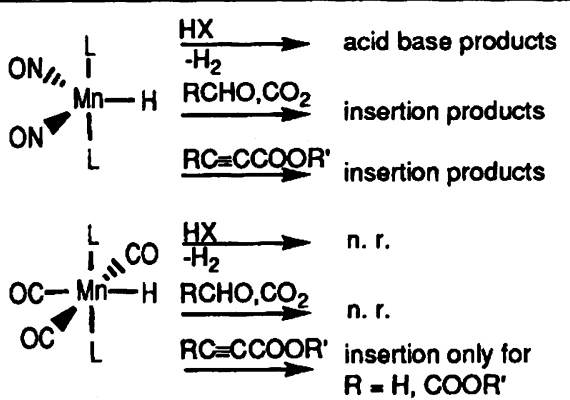

\section{Notiz / Note}

\section{7 \\ Rieger*, B., Jany, G.}

Eine bequeme Synthese enantiomerenreiner Ethylenverbrückter Metallocen-Komplexe mit Fluorenyl- und Octahydrofluorenyl-Liganden

A Convenient Synthesis of Enantiomerically Pure Ethylene-Bridged Metallocene Complexes Bearing Fluorenyl- and Octahydrofluorenyl Ligands

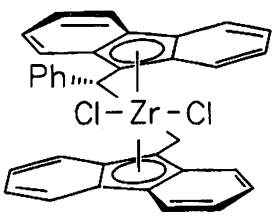

A

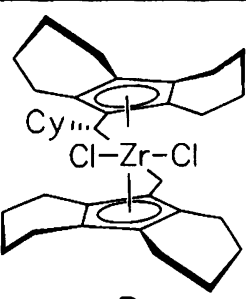

B

\section{- Teil B: Organische Chemie / Part B: Organic Chemistry}

2423 Dunsch, L., Gollas, B., Neudeck, A., Petr, A., Speiser*, B., Stahl, H.

Elektrochemie von Triazenen, 3. - Ein-Elektron-Oxidation von Aryltriazenen zu Radikalkationen

Electrochemistry of Triazenes, 3. - One-Electron Oxidation of Aryltriazenes to Radical Cations

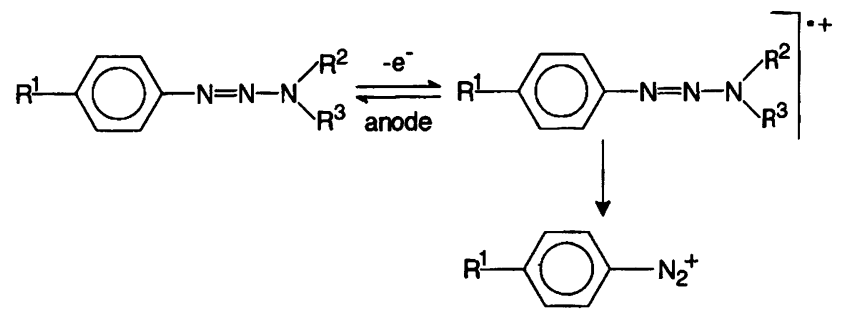


Regioselektive Protonierung von Allyllithium-Verbindungen

Regioselective Protonation of Allyllithium Compounds

Schwesinger*, R., Willaredt, J., Schlemper, H., Keller, M., Schmitt, D., Fritz, H.

Neue, sehr starke ungeladene Hilfsbasen; Entwurf und Synthese von monomeren und Polymer-gebundenen Triaminoiminophosphoran-Basen mit breit variiertem sterischem Anspruch

Novel, Very Strong, Uncharged Auxiliary Bases; Design and Synthesis of Monomeric and Polymer-Bound Triaminoiminophosphorane Bases of Broadly Varied Steric Demand

Schneider, U., Schneider*, H.-J.

Synthese und Eigenschaften von Makrocyclen aus Resorcinen sowie von entsprechenden Derivaten und Wirt-Gast-Komplexen

Synthesis and Properties of Macrocycles from Resorcinol, Corresponding Derivatives and Host-Guest Complexes

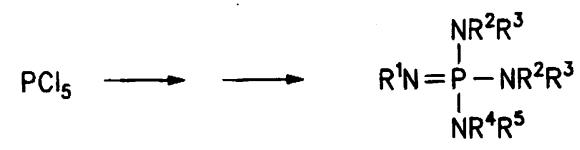

Jamrozik*, J., Żesławski, W.

Propellane, 10. - Bis- und Tris(propellane) aus Methylbenzolen: $\quad 1,2 ; 3,4 ; 5,6$-Tris $\left\{8^{\prime}, 11^{\prime}\right.$-dioxa[4.3.3]propella $\left.\left(3^{\prime}, 4^{\prime}\right)\right\}$ benzol

Propellanes, 10. - Bis- and Tris(propellanes) from Methylbenzenes: $\quad 1,2 ; 3,4 ; 5,6$-Tris $\left\{8^{\prime}, 11^{\prime}\right.$-dioxa[4.3.3]propella $\left.\left(3^{\prime}, 4^{\prime}\right)\right\}$ benzene
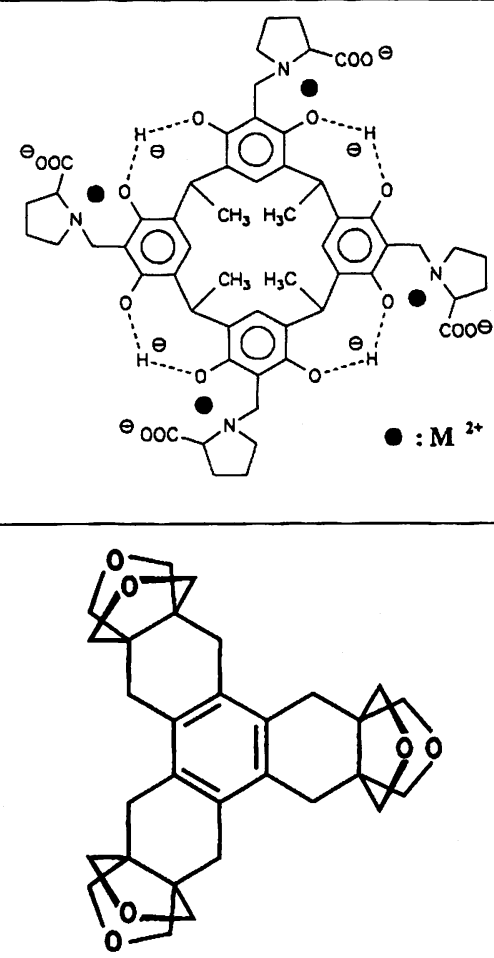

Aumann*, R., Jasper, B., Läge, M., Krebs, B. Organische Synthesen mit Übergangsmetall-Komplexen, 74. - Neue Phosphonium-allenid- und 2-Phosphanylethenyl-Carben-Chrom- und -Wolfram-Komplexe

Organic Syntheses via Transition Metal Complexes, 74. - Novel Phosphonium Allenide and 2-Phosphanylethenyl Carbene Chromium and Tungsten Complexes
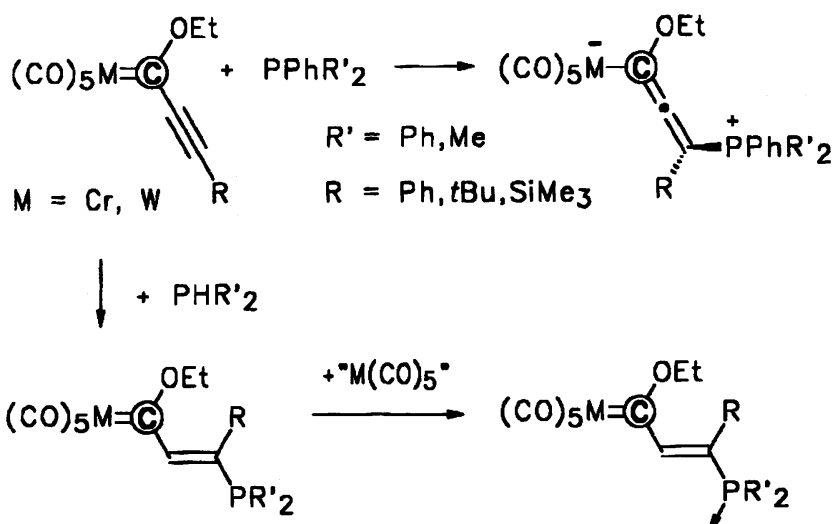

$R^{\prime}=t B u, c C y$

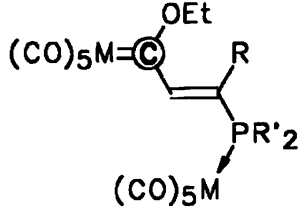


Hamuryudan, E., Bekaroğlu*, Ö.

Synthese und Komplexierung eines neuen 14gliedrigen $\mathrm{N}_{2} \mathrm{O}_{2}$-Makrocyclus mit vic-Dioxim-Gruppen

Synthesis and Complexation of a New 14-Membered $\mathrm{N}_{2} \mathrm{O}_{2}$ Macrocycle with vic-Dioxime Moieties

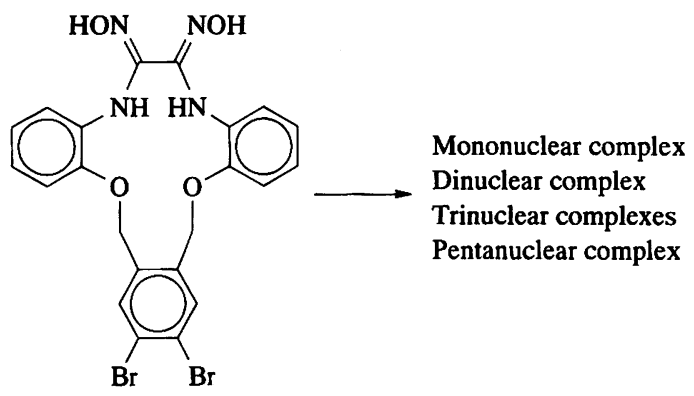

Saalfrank*, R. W., Struck, O., Davidson, M. G., Snaith, R.

Koordinationspolymere, IX. - Synthese und Kristallstruktur eines 1D-Natrium-Koordinationspolymers: $\left[\mathrm{NaL}^{4} \text { (PMDETA) }\right]_{\infty}$

Coordination Polymers, IX. - Synthesis and Crystal Structure of a 1D-Sodium Coordination Polymer: $\left[\mathrm{NaL}^{4}(\mathrm{PMDETA})\right]_{\infty}$

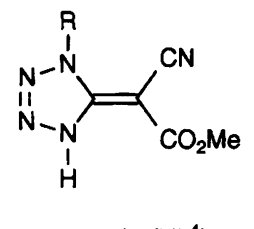

$1\left(H L^{4}\right)$
1. $\mathrm{NaH}$

\section{PMDETA}

$-\mathrm{H}_{2}$

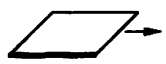

2

3

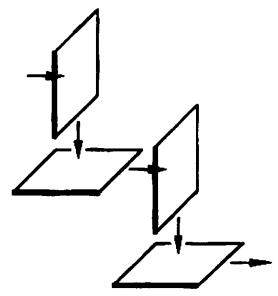

The electrophilicity of ferrocenylmethylium ions is compared with that of other carbenium ions

Wie elektrophil sind Ferrocenylmethyl-Kationen? Kinetik ihrer Reaktionen mit $\pi$-Nucleophilen und Hydrid-Donatoren

How Electrophilic are Ferrocenylmethyl Cations? Kinetics of their Reactions with $\pi$ Nucleophiles and Hydride Donors

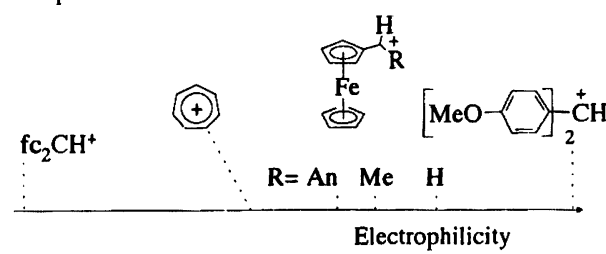

\section{Stöckigt, D., Schwarz*, H.}

Abstimmung der Reaktivität durch Liganden-Effekte: Gasphasen-Reaktionen von $\mathrm{Fe}\left(\mathrm{C}_{6} \mathrm{H}_{6}\right) \mathrm{O}^{+}$anstelle von „nacktem“ $\mathrm{FeO}^{+}$

Reactivity Tuning by Ligand Effects: Gas-Phase Reactions of $\mathrm{Fe}\left(\mathrm{C}_{6} \mathrm{H}_{6}\right) \mathrm{O}^{+}$versus "Bare" $\mathrm{FeO}^{+}$

2505 Beckmann, M., Meyer, T., Schulz, F., Winterfeldt*, E.

Seiten-selektive und endo-selektive Cycloadditionen mit enantiomerenreinen Cyclopentadienen

Face-Selective and endo-Selective Cycloadditions with Enantiomerically Pure Cyclopentadienes

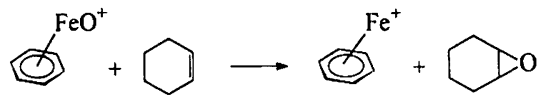

\section{Hoffmann*, R. W., Stürmer, R.}

Stereoselektive Synthese von Alkoholen, XLVII. Anwendungen von chiralen Z-Pentenylboronaten bei der Herstellung von Erythronolid-Synthese-Bausteinen

Stereoselective Synthesis of Alcohols, XLVII. - Application of Chiral Z-Pentenylboronates to the Synthesis of Erythronolide Building Blocks

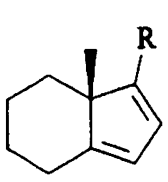

$(S)-3$<smiles>[R]C1=CC=C2CCCC[C@]12C</smiles>

(R)-3

\begin{tabular}{l|l} 
3 & $\mathbf{R}$ \\
\hline a & $\mathrm{C}_{6} \mathrm{H}_{5}$ \\
b & $4-\mathrm{H}_{3} \mathrm{COC}_{6} \mathrm{H}_{4}$ \\
c & $2-\mathrm{H}_{3} \mathrm{COC}_{6} \mathrm{H}_{4}$ \\
d & $2,4-\left(\mathrm{H}_{3} \mathrm{CO}\right)_{2} \mathrm{C}_{6} \mathrm{H}_{3}$ \\
e & 2-naphthyl
\end{tabular}<smiles>CC[C@H](C)[C@H]1O[C@@H](c2ccc(OC)cc2)O[C@@H]([C@H](C)CI)[C@@H]1C</smiles><smiles>[3H]OC(=O)[C@H](C)[C@H]1O[C@@H](c2ccc(OC)cc2)O[C@H](C(C)=O)[C@@H]1C</smiles> 
Stereoselektive Synthese von Alkoholen, XLVIII. Eine gezielte Synthese von (9S)-Dihydro-erythronolid A Stereoselective Synthesis of Alcohols, XLVIII. - Linear Synthesis of (9S)-Dihydro-erythronolide A

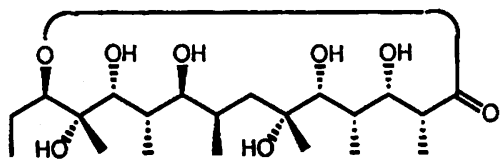

Photochemische und thermische Erzeugung von Thiocarbonylyliden aus 2,5-Dihydro-1,3,4-thiadiazolen

Photochemical and Thermal Generation of Thio-<smiles>[R]C1([R])N=NCSS1</smilesstem Magnesiumoxid/Kalium

Heterogeneous Gasphase Eliminations with the System Magnesium Oxide/Potassium

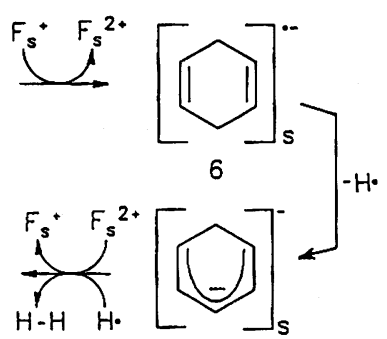

7

$2535 \quad$ Nehl, $\mathbf{H}$.

$\left(\eta^{3}\right.$-Allyl)( $\eta^{5}$-pentamethylcyclopentadienyl)cobalt ein selektiver Katalysator für die Pyridinsynthese $\left(\eta^{3}\right.$-Allyl $)\left(\eta^{5}\right.$-pentamethylcyclopentadienyl)cobalt - a Selective Catalyst for the Pyridine Synthesis

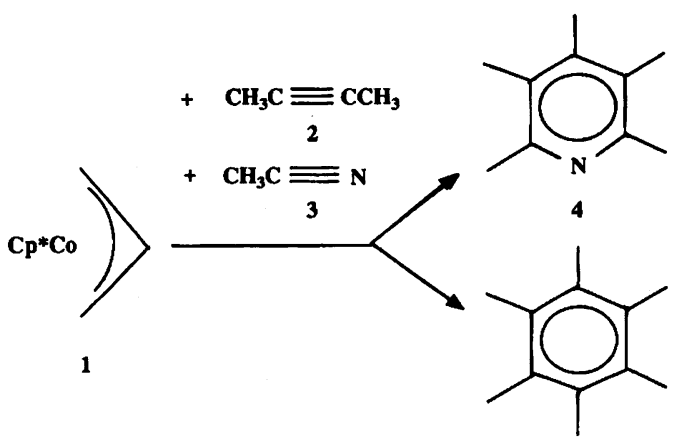

5

2539 K. Albrecht, A. de Meijere*

Palladium-katalysierte Mehrfach-Kupplungs-Reaktionen von $\beta$-Bromstyrol mit Norbornen und Dicyclopentadien

Palladium-Catalysed Multiple Coupling Reactions of $\beta$-Bromostyrene with Norbornene and Dicyclopentadiene

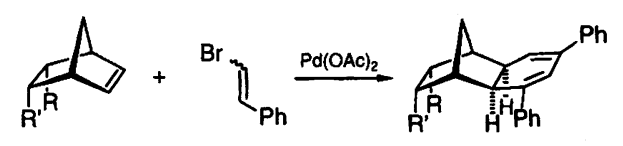

\section{Register / Index}




\title{
How Electrophilic are Ferrocenylmethyl Cations? Kinetics of their Reactions with $\pi$ Nucleophiles and Hydride Donors ${ }^{\text {ht }}$
}

\author{
Herbert Mayr* and Doris Rau \\ Institut für Organische Chemie der Technischen Hochschule Darmstadt, \\ Petersenstraße 22, D-64287 Darmstadt, Germany
}

Received June 30, 1994

Key Words: Electrophilicity / Ferrocenylmethylium ions / Kinetics

Second-order rate constants for the reactions of the ferrocenylmethylium ions $2 a-e$ with silyl enol ethers, allylsilanes, allylstannanes, and hydride donors have been determined photometrically and conductometrically in dichloromethane. The ferrocenylmethylium ions $2 \mathrm{a}-\mathbf{d}$ (fc-CHR ${ }^{+}, \mathrm{R}=\mathrm{H}, \mathrm{Me}$,
$\mathrm{Ph}, \mathrm{An}$ ) are slightly stronger electrophiles than the tropylium ion, and their electrophilic reactivities depend only slightly on the nature of $R$. The bis(ferrocenyl)methylium ion $2 e$ is a considerably weaker electrophile, comparable to the tricarbonyl(cyclohexadienyl)iron cation.
Combinations of electrophiles with nucleophiles represent the most important reaction type in organic chemistry, and there have been numerous attempts to quantify the terms electrophilicity and nucleophilicity ${ }^{[1]}$. It is wellknown that relative reactivities of electrophiles and nucleophiles are not generally independent of the nature of the reaction partner. In the case of the reactions of benzhydryl cations with $\pi$ nucleophiles (alkenes ${ }^{[2,3]}$, allylsilanes and -stannanes ${ }^{[4]}$, arenes ${ }^{[5]}$ ) and hydride donors ${ }^{[6,7]}$ the relative nucleophilicities depend only slightly on the nature of the reference carbenium ion. Taking into account the different slopes of the linear free energy relationships, nucleophilicity parameters have been derived ${ }^{[8]}$ which have been reported to hold also for the corresponding reactions with tricarbonyl(cycloalkadienyl)iron cations ${ }^{[9]}$. Recently, we have linked our kinetic data with related rate constants determined by other groups, and thus have obtained the correlation equation (1), which has been demonstrated to be applicable to a large variety of electrophile-nucleophile combinations ${ }^{[8]}$.

$$
\left.\lg k=s(E+N) \text { (aprotic solvents, } 20^{\circ} \mathrm{C}\right)
$$

In this equation, electrophiles are characterized by a single parameter $(E)$, while nucleophiles are characterized by the nucleophilicity parameter $N$ and the slope parameter $s$. The application of this scale is hampered by the fact, however, that in contrast to the large number of nucleophilicity parameters which are already available, there is only a relatively small number of electrophiles, the reactivity of which has been established quantitatively. We have, therefore, started a program to assign reactivity parameters to various classes of electrophiles.

Only few years after its discovery in $1951^{[10]}$, the ability of ferrocene to stabilize positive charge has been recognized ${ }^{[11,12]}$. Ferrocenylmethylium ions have been isolated as stable salts, e.g. as tetrafluoroborates ${ }^{[13]}$, and numerous spectroscopic, mechanistic, and crystal structural investigations on these ions have been published ${ }^{[14]}$. Several groups have studied the kinetics of their reactions with $\mathbf{n}$ nucleophiles and anionic hydride donors ${ }^{[1,13,15,16]}$.

In this work, we have studied the kinetics of the reactions of ferrocenylmethylium ions with $\pi$ nucleophiles and neutral hydride donors in order to quantify their electrophilicity and to characterize the electrophilic potential of these cations.

\section{Reaction Products}

Though ferrocenylmethylium ions are relatively stable entities, their handling requires some care. Some of the free cations are sensitive to moisture, and in the case of alkylsubstituted ferrocenylmethylium ions, deprotonation may occur to give alkenylferrocenes which may successively react with ferrocenylmethylium ions to yield undesired oligomeric byproducts ${ }^{[16]}$. In order to circumvent these problems, we have usually generated solutions of the ferrocenylmethylium ions from the corresponding acetoxy derivatives and a Lewis acid immediately before use (Scheme 1).

Scheme 1. [a] An = 4- $\mathrm{MeOC}_{6} \mathrm{H}_{4}$, [b] fc = Ferrocenyl, $\mathrm{C}_{5} \mathrm{H}_{5} \mathrm{FeC}_{5} \mathrm{H}_{4}$

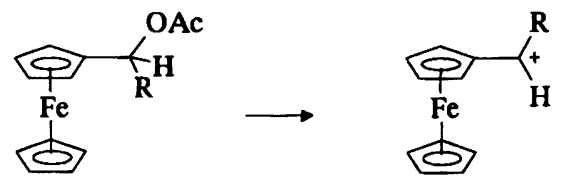

\begin{tabular}{lll}
$R$ & & \\
\hline$H$ & $1 a$ & $2 a$ \\
$M e$ & $1 b$ & $2 b$ \\
Ph & $1 c$ & $2 c$ \\
An[a] & $1 d$ & $2 d$ \\
fc[b] & & $2 e$ \\
\hline
\end{tabular}

Successive treatment of the ferrocenyl derivatives 1a-d with $\mathrm{ZnCl}_{2} \cdot \mathrm{Et}_{2} \mathrm{O}_{1.6}$ and the nucleophiles 3-9 gives the products listed in Scheme 2 as the only compounds detectable by NMR. The reactions of 2e with 6 and 8 have been performed with $2 \mathrm{e} \cdot \mathrm{BF}_{4}$. 
As indicated in Scheme 2, several of the reaction products have been described before, and since the NMR spectra confirm the expected and well-established course of the reactions of electrophiles with allylstannanes, allylsilanes ${ }^{[4,17]}$, silylenol ethers ${ }^{[18,19]}$, and hydride donors ${ }^{[7,20]}$, further analytical data for the reaction products have not been collected.

Scheme 2. Reactions of ferrocenylmethylium ions with $\pi$ nucleophiles and $\mathrm{HSiMe}_{2} \mathrm{Ph}$. - [a]-[d] Product previously described in [a] ref. ${ }^{[3]}$, [b] ref. ${ }^{[34]}$, [c] ref. ${ }^{[35]}$, [d] ref. ${ }^{[31,36]}$

\begin{tabular}{|c|c|c|c|c|}
\hline Nucleophile & & Electrophile/R & Product & \\
\hline $\mathrm{SnPh}_{3}$ & 3 & $2 c / \mathrm{Ph}$ & P & 3c \\
\hline $\mathrm{SiMe}_{3}$ & 4 & $\begin{array}{c}2 \mathrm{~b} / \mathrm{Me} \\
2 \mathrm{c} / \mathrm{Ph} \\
2 \mathrm{~d} / \mathrm{An}\end{array}$ & & $\begin{array}{l}4 b \\
4 c \\
4 d\end{array}$ \\
\hline $\mathrm{iMe}_{3}$ & 5 & $\begin{array}{l}2 c / P h \\
2 d / A n\end{array}$ & & $\begin{array}{l}5 \mathrm{cla}^{\mathbf{a}]} \\
\mathbf{5 d}\end{array}$ \\
\hline $\mathrm{OSiMe}_{3}$ & 6 & $\begin{array}{c}2 c / P h \\
2 d / A n \\
2 e / f c\end{array}$ & & $\begin{array}{l}6 c \\
6 d \\
6 e\end{array}$ \\
\hline $\mathrm{OSiMe}_{3}$ & 7 & $2 \mathrm{~b} / \mathrm{Me}$ & & $7 \mathbf{b}[\mathbf{b}]$ \\
\hline $\mathrm{SiMe}_{3}$ & 8 & $2 \mathrm{e} / \mathrm{fc}$ & & $8 e$ \\
\hline $\mathrm{HSiMe}_{2} \mathrm{Ph}$ & 9 & $\begin{array}{l}2 \mathrm{a} / / \mathrm{H} \\
2 \mathrm{~d} / \mathrm{An}\end{array}$ & fc & $\begin{array}{l}9 \mathrm{a}[c] \\
9 \mathrm{~d}[\mathrm{~d}]\end{array}$ \\
\hline
\end{tabular}

\section{Kinetic Investigations}

In previous kinetic investigations of the reactions of carbenium ions with allylstannanes, silylated enol ethers, and hydrosilanes problems have been encountered due to the reactions of these nucleophiles with some of the Lewis acids employed in excess for the generation of the carbenium ions. Since trimethylsilyl triflate has been observed not to react with any of the nucleophiles 3-11, the reaction of trimethylsilyl triflate with the ferrocenylmethyl acetates 1 has been employed to produce colored solutions of the ferrocenylmethylium triflates for the kinetic experiments. When the nucleophiles 3-11 are added successively, decolorization takes place. Its rate is followed photometrically and conductometrically as described previously ${ }^{[21]}$. In accord with studies of other carbocations ${ }^{[2,21]}$, the reactions follow second-order kinetics, first order with respect to carbenium ion and first order with respect to nucleophile. Since related investigations show independence of the rate constants of the nature of the negative counterion ${ }^{[2,4,7,21]}$, the $k_{2}$ values given in Table 1 can be considered to represent the rate constants of the attack of the ferrocenylmethylium ions at the nucleophiles.
Table 1. Rate constants for the reactions of ferrocenylmethyl cations fcCHR ${ }^{+[\mathrm{a}]}$ with nucleophiles $\left(20^{\circ} \mathrm{C}, \mathrm{CH}_{2} \mathrm{Cl}_{2}\right)$

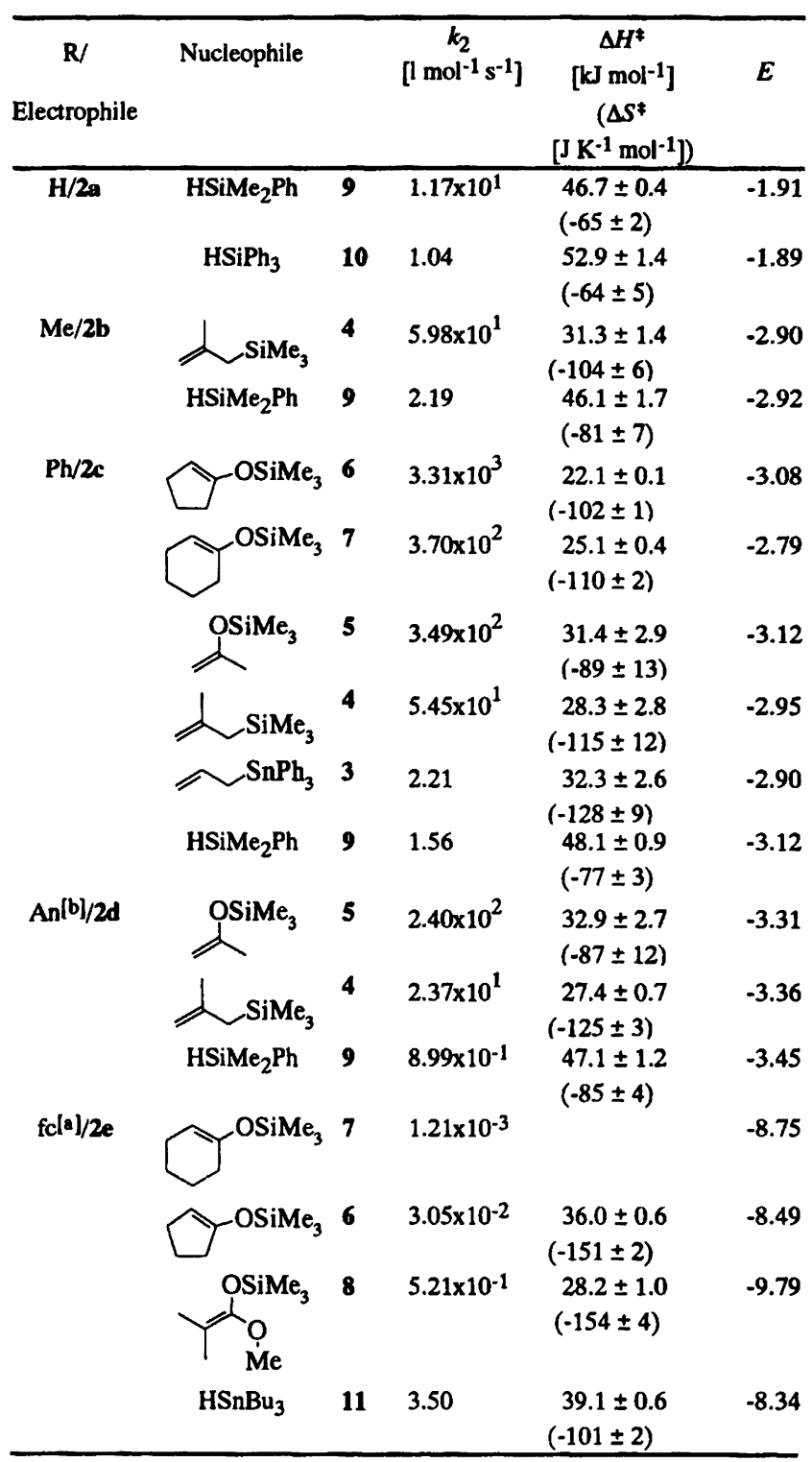

${ }^{[a]} \mathrm{fc}=\left(\mathrm{C}_{5} \mathrm{H}_{5}\right) \mathrm{Fe}\left(\mathrm{C}_{5} \mathrm{H}_{4}\right) .-{ }^{[b]} \mathrm{An}=4-\mathrm{MeOC}_{6} \mathrm{H}_{4}$.

\section{Discussion}

The activation parameters in Table 1 show that within one class of nucleophiles the reactivity differences are due to variable values of $\Delta H^{\ddagger}$ while $\Delta S^{\ddagger}$ remains almost constant. As in analogous reactions with benzhydryl cations, there are characteristic values of $\Delta S^{\neq}$for the reactions of alkyl- and aryl-substituted ferrocenylmethylium ions with the different classes of nucleophiles. While most $\pi$ nucleophiles used in this study possess activation entropies of $(-105 \pm 15) \mathrm{J} \mathrm{mol}^{-1} \mathrm{~K}^{-1}$, the corresponding values for the hydride donors $\mathrm{HSiMe}_{2} \mathrm{Ph}$ and $\mathrm{HSiPh}_{3}$ are noticeably less negative $(-81 \pm 5) \mathrm{J} \mathrm{mol}^{-1} \mathrm{~K}^{-1}$. Unusually large negative values of $\Delta S^{\ddagger}$ have only been found for the reactions of $2 \mathrm{e}$ with $\pi$ nucleophiles and $\mathrm{HSnBu}_{3}$, which may be due to the larger steric shielding of this cation. An X-ray analysis of $2 \mathrm{e}$ reveals the transoid conformation of the cation. The 
cyclopentadienyl rings are almost eclipsed, and the ferrocenyl groups are bent toward the carbenium carbon ${ }^{[22]}$. Consequently, the $\pi$ orbital of the carbenium center is shielded from both sides. An analogous increase of the negative value of $\Delta S^{\neq}$due to steric effects has been reported in ref. ${ }^{[9]}$.

Eq. (1) can now be used to calculate the $E$ values for the electrophiles $2 \mathbf{a}-\mathbf{e}$ from $\lg k_{2}$ (Table 1 ) and the nucleophilicity parameters $N$ and $s$ for 3-11 given in ref. ${ }^{[8]}$. The last column in Table 1 shows that the electrophilicity parameters $E$ determined from the reactivities toward different nucleophiles are closely similar, indicating that ferrocenylmethylium ions match the linear free energy relationship (1). Only in the case of $2 e$ steric effects play a noticeable role, and the bulky nucleophile 8 reacts more slowly than expected from the reactivities of the other nucleophiles. The graphical presentation of these reactivities in Figure 1 also shows that ferrocenylmethylium ions and benzhydryl cations follow the same linear free energy relationship.

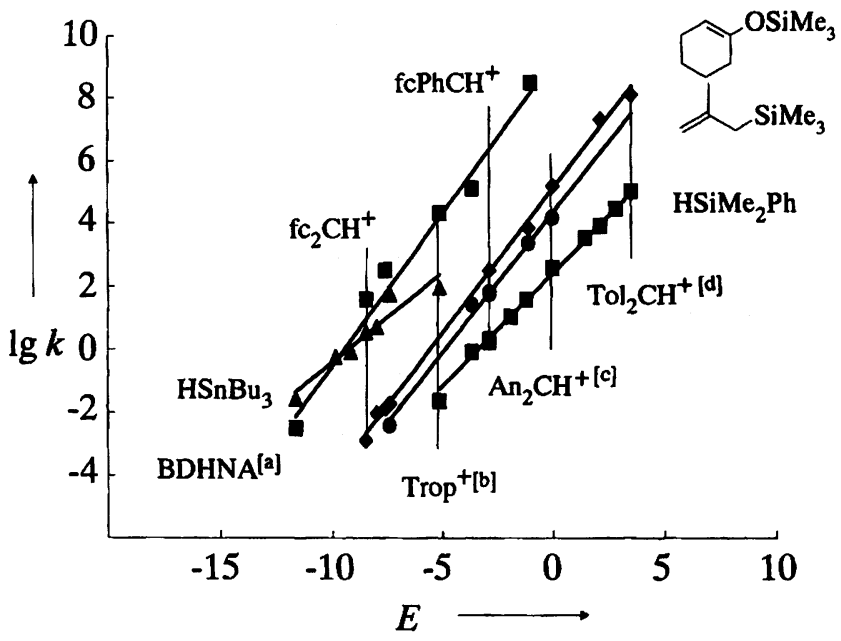

Figure 1. Correlation between the rate constants of the reactions of electrophiles with nucleophiles and the electrophilicity parameters given in Table 1 and ref. $^{[8]}$

[a] BDHNA: $N$-Benzyl-1,4-dihydronicotinamide. - [b] Trop ${ }^{+}$: Tropylium ion. - ${ }^{[c]} \mathrm{An}_{2} \mathrm{CH}^{+}$: Bis(4-methoxyphenyl)carbenium ion. dd] $\mathrm{Tol}_{2} \mathrm{CH}^{+}$: Bis(4-methylphenyl)carbenium ion.

The rate constants given in Table 1 were combined with the rate constants reported for the reactions of ferrocenylmethylium ions $2 \mathrm{c}$, d with $\mathrm{H}_{2} \mathrm{O}$ and $\mathrm{N}$-benzyl-1,4-dihydronicotinamide (BDHNA) ${ }^{[11,13]}$ to give the averaged $E$ values compiled in Figure 3. The reactivity order of the cations 2a-d reveals that replacement of a hydrogen by a methyl, a phenyl, or a $p$-anisyl group in 2 a reduces the reactivity by less than two orders of magnitude, indicating little electron demand of the formal carbenium center of 2a. Only when a second ferrocenyl group is introduced (cation 2e), a strong reduction of electrophilicity is observed. The relatively small differences of the electrophilic reactivities of the cations $\mathbf{2 a}-\mathbf{d}$ can be rationalized by their structures. X-ray analysis of ferrocenyldiphenylcarbenium tetrafluoroborate ${ }^{[23]}$ manifests an $\mathrm{Fe}-\mathrm{C}_{\text {exo }}$ distance of $271.5 \mathrm{pm}$, and $\mathrm{C}_{\text {exo }}$ is bent to iron (angle $20.7^{\circ}$ ). The direct interaction of the cationic $\mathrm{C}_{\text {exo }}$ with the iron atom essentially stabilizes the ferrocenylmethylium ions. Hence, the cation can also be described as an $\eta^{6}$ iron-fulvene complex with little charge at $\mathbf{C}_{\text {exo. }}$.

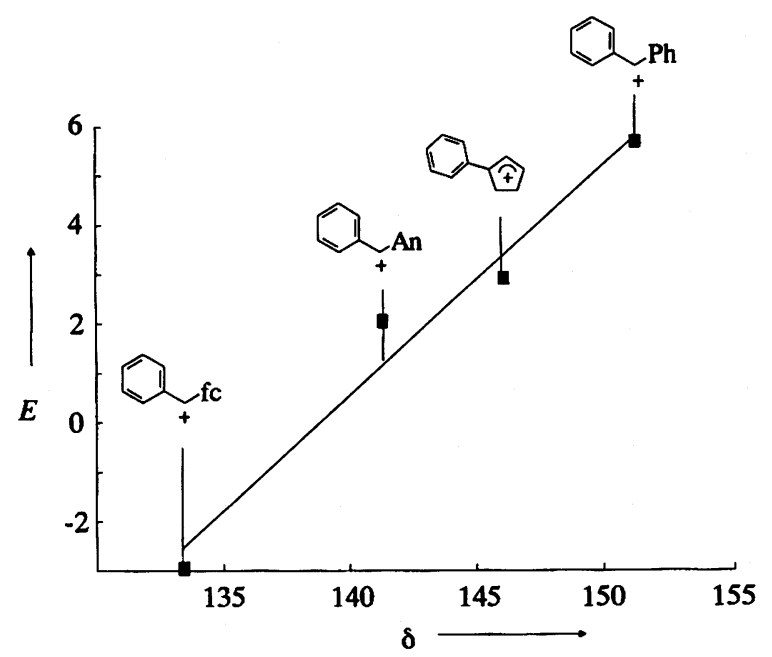

Figure 2. Correlation of the electrophilicity parameter $E$ with the ${ }^{13} \mathrm{C}$ NMR chemical shift of $C_{p a r a}$ in phenyl-substituted carbenium ions

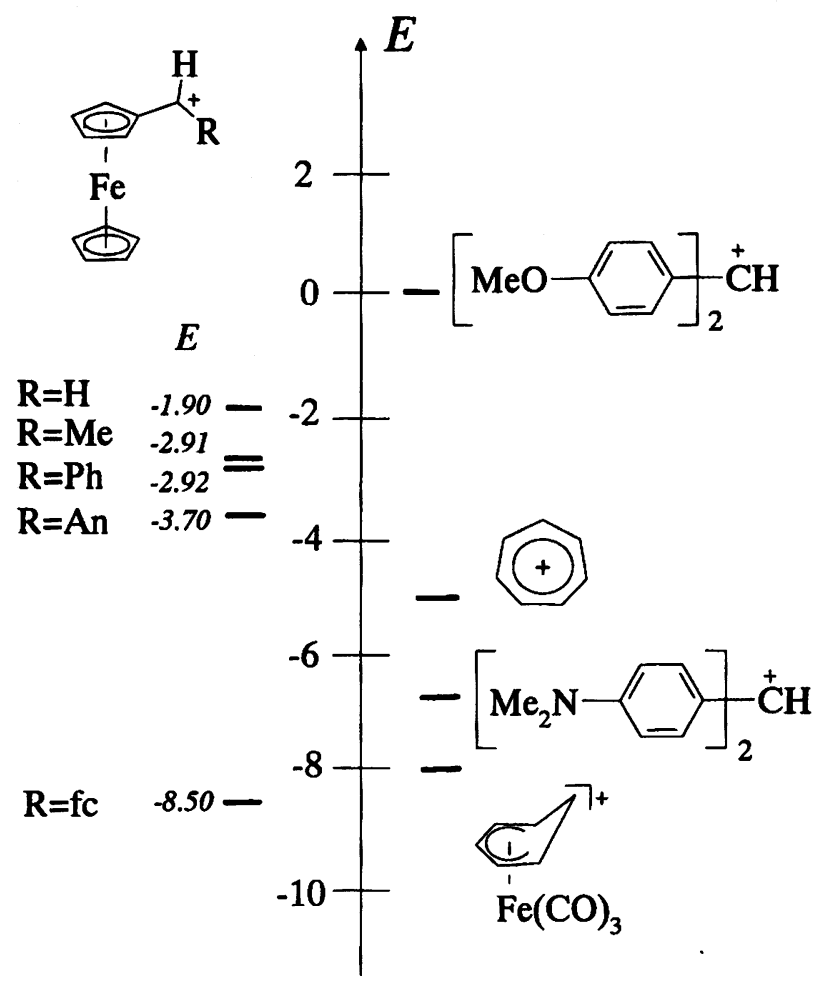

Figure 3. Comparison of the electrophilicity parameters $E$ of ferrocenylmethylium ions with those of other carbenium ions

${ }^{13} \mathrm{C}-\mathrm{NMR}$ chemical shifts of the para-carbons in phenylsubstituted carbenium ions have been used as a probe for determining the positive charge at the carbenium center ${ }^{[24]}$. A comparison of $\delta\left(\mathrm{C}_{\mathrm{para}}\right)$ of $2 \mathrm{c}$ with the corresponding chemical shifts of other phenyl-substituted carbenium ions (Figure 2) also leads to the conclusion that the positive charge in ferrocenylmethylium ions is located only to a small extent on $\mathrm{C}_{\text {exo }}$. Figure 2 furthermore shows that this 
chemical shift shows a fair correlation with the electrophilicity parameter $E$ of these compounds.

As indicated in Figure 3, the unsubstituted, methyl-, phenyl-, and anisyl-substituted ferrocenylmethylium ions are slightly stronger electrophiles than the tropylium ion. Their electrophilicity lies between the well-established bis $[p$ (dimethylamino)phenyl]- and bis( $p$-methoxyphenyl) carbenium ions ${ }^{[18,25]}$, while the bis(ferrocenyl)methylium ion $2 \mathbf{e}$ is a considerably weaker electrophile.

Financial support by the Volkswagen-Stiftung and the Fonds der Chemischen Industrie is gratefully acknowledged. We thank Mr. $O$. $K u h n$ for experimental collaboration and Dr. M. Patz for discussions.

\section{Experimental}

NMR: Bruker WM 300. All NMR spectra (300 MHz) were recorded in $\mathrm{CDCl}_{3}$. - Ferrocenecarbaldehyde (Aldrich) was reduced with $\mathrm{LiAlH}_{4}$ to give ferrocenemethanol ${ }^{[26]}\left(76 \%\right.$, ref. $\left.{ }^{[26]} 90 \%\right)$ which was treated with acetic anhydride/pyridine to give the acetate 1a according to ref. ${ }^{[27]}(87 \%)$. Reaction of ferrocene with acetic anhydride/ $\mathrm{BF}_{3}{ }^{[28]}$, benzoyl chloride/AlCl ${ }_{3}^{[29]}$ or $p$-anisoyl chloride/ $\mathrm{AlCl}_{3}$ according to ref. ${ }^{[29]}$ gave ferrocenyl methyl ketone $\left(72 \%\right.$, ref. ${ }^{[28]}$ $67 \%)$, ferrocenyl phenyl ketone $\left(72 \%\right.$, ref. $\left.{ }^{[29]} 70-75 \%\right)$, and ferrocenyl ( $p$-anisyl) ketone (38\%), respectively. Reduction with $\mathrm{LiAlH}_{4}$ and subsequent acetylation with acetic anhydride/pyridine according to ref. ${ }^{[27]}$ gave compounds $1 b^{[27]}(82 \%)$, 1 c $(87 \%)$, and $1 \mathrm{~d}(73 \%)$. For the preparation of the bis(ferrocenyl) compounds, bis(ferrocen$\mathrm{yl})$ methyl ethyl ether $\left(\mathrm{fc}_{2} \mathrm{CHOEt}\right)$ was prepared from ferrocene and triethyl orthoformate according to a procedure by Schaaf ${ }^{[30]}$. Treatment of $\mathrm{fc}_{2} \mathrm{CHOEt}$ with $\mathrm{HBF}_{4}$ or $\mathrm{CF}_{3} \mathrm{SO}_{3} \mathrm{H}$ according to ref. ${ }^{[31]}$ gave a deep blue powder of $\mathrm{fc}_{2} \mathrm{CH}^{+} \mathrm{BF}_{4}^{-}(88 \%)$ and $\mathrm{fc}_{2} \mathrm{CH}^{+} \mathrm{CF}_{3^{-}}$ $\mathrm{SO}_{3}^{-}(92 \%)$, respectively.

General Procedure for the Reactions of Ferrocenylmethylium Ions with Nucleophiles: Compounds $1 \mathrm{a}-\mathbf{d}(\approx 1 \mathrm{mmol})$ were dissolved in dry $\mathrm{CH}_{2} \mathrm{Cl}_{2}(10 \mathrm{ml})$. The solutions were cooled at $-50^{\circ} \mathrm{C}$, and 0.5 $\mathrm{ml}$ of a $2 \mathrm{M}$ solution of $\mathrm{ZnCl}_{2} \cdot\left(\mathrm{OEt}_{2}\right)_{1.6}{ }^{[32]}$ in $\mathrm{CH}_{2} \mathrm{Cl}_{2}$ was added to give deep-red solutions of the ferrocenylmethyl cations. After addition of 3 equiv. of 3-9 the solutions were allowed to warm up to $20^{\circ} \mathrm{C}$ ( $\left.30 \mathrm{~min}\right)$. Decolorization took place, and the solutions were washed with water $(20 \mathrm{ml})$. The aqueous layer was extracted with two 5-ml portions of $\mathrm{CH}_{2} \mathrm{Cl}_{2}$, and the combined organic fractions were then washed with $\mathrm{NaHCO}_{3}$ (saturated aq. solution) and water and dried with $\mathrm{MgSO}_{4}$. The solvent was evaporated in vacuo and the residue analyzed by ${ }^{1} \mathrm{H}$ and ${ }^{13} \mathrm{C}$ NMR. Compounds $6 e$ and $8 \mathrm{e}$ were obtained by dissolving 2e-OTf $(1 \mathrm{mmol})$ in $30 \mathrm{ml}$ of $\mathrm{CH}_{2} \mathrm{Cl}_{2}$, adding the nucleophiles 6 and 8 , respectively to the solution, and workup as described above.

(1-Phenyl-3-butenyl)ferrocene (3c): Orange powder, m.p. $46-46.5^{\circ} \mathrm{C}$ (ether/hexane, $1: 1$ ). $-{ }^{1} \mathrm{H}$ NMR: $\delta=2.55-2.65$, $2.80-2.88(2 \mathrm{~m}, 2 \mathrm{H}, 2-\mathrm{H}), 3.68$ (dd, $J=4.7 / 10.4 \mathrm{~Hz}, 1 \mathrm{H}, 1-\mathrm{H})$, $3.94,4.04,4.09,4.13$ ( 4 br. s, $\left.4 \mathrm{H}, \mathrm{C}_{5} \mathrm{H}_{4}\right), 4.06\left(\mathrm{~s}, 5 \mathrm{H}, \mathrm{C}_{5} \mathrm{H}_{5}\right)$, 4.90-5.02 (m, 2H, 4-H), 5.62-5.75 (m, 1 H, 3-H), 7.14-7.28 (m, $5 \mathrm{H}$, aromatic $\mathrm{H}) .-{ }^{13} \mathrm{C}$ NMR: $\delta=41.41(\mathrm{t}, \mathrm{C}-2), 46.16(\mathrm{~d}, \mathrm{C}-1)$, $66.83,66.90,67.45,67.56\left(4 \mathrm{~d}, \mathrm{C}_{5} \mathrm{H}_{4}\right), 68.55\left(\mathrm{~d}, \mathrm{C}_{5} \mathrm{H}_{5}\right), 93.68(\mathrm{~s}, \mathrm{fc}-$ $\mathrm{C}_{i}$ ), $115.86(\mathrm{t}, \mathrm{C}-4), 126.10,127.89,128.07$ (3 d, aromatic C), 137.03 (d, C-3), 144.78 (s, $\mathrm{C}_{i}$-aryl).

(1,3-Dimethyl-3-butenyl)ferrocene (4b): Orange oil. - ${ }^{1} \mathrm{H}$ NMR: $\delta=1.09\left(\mathrm{~d}, J=6.8 \mathrm{~Hz}, 3 \mathrm{H}, 1-\mathrm{CH}_{3}\right), 1.67(\mathrm{t}, J=0.5 \mathrm{~Hz}, 3 \mathrm{H}, 3-$ $\mathrm{CH}_{3}$ ), 1.95 (dd, $J=10 / 13.5 \mathrm{~Hz}, 1 \mathrm{H}, 2-\mathrm{H}$ ), 2.28 (dd, $J=4.4 / 13.5$ $\mathrm{Hz}, 1 \mathrm{H}, 2-\mathrm{H}), 2.56\left(\mathrm{~m}_{\mathrm{c}}, 1 \mathrm{H}, 1-\mathrm{H}\right), 3.99\left(\mathrm{~m}_{\mathrm{c}}, 4 \mathrm{H}, \mathrm{C}_{5} \mathrm{H}_{4}\right), 4.06(\mathrm{~s}$, $\left.5 \mathrm{H}, \mathrm{C}_{5} \mathrm{H}_{5}\right), 4.60,4.69$ (2 br. s, $\left.2 \mathrm{H}, 4-\mathrm{H}\right) .-{ }^{13} \mathrm{C}$ NMR: $\delta=20.10$,
22.28 ( 2 q, $\mathrm{CH}_{3}$ ), 30.73 (d, C-1), 47.22 (t, C-2), 65.94, 66.76, 66.84, $66.88\left(4 \mathrm{~d}, \mathrm{C}_{5} \mathrm{H}_{4}\right), 68.34\left(\mathrm{~d}, \mathrm{C}_{5} \mathrm{H}_{5}\right), 95.96\left(\mathrm{~s}, \mathrm{fc}^{-\mathrm{C}_{i}}\right), 111.83(\mathrm{t}, \mathrm{C}-4)$, 144.29 (s, C-3).

(3-Methyl-1-phenyl-3-butenyl)ferrocene (4c): Orange powder, m.p. $54^{\circ} \mathrm{C}$ (ether). ${ }^{-1} \mathrm{H}$ NMR: $\delta=1.69\left(\mathrm{~s}, 3 \mathrm{H}, 3-\mathrm{CH}_{3}\right), 2.58(\mathrm{dd}$, $J=11.1 / 13.6 \mathrm{~Hz}, 1 \mathrm{H}, 2-\mathrm{H}), 2.83$, (dd, $J=4.2 / 13.6 \mathrm{~Hz}, 1 \mathrm{H}, 2-\mathrm{H})$, 3.81 (dd, $J=4.3 / 11.1 \mathrm{~Hz}, 1 \mathrm{H}, 1-\mathrm{H}), 3.96,4.04,4.09,4.16$ (4 br. s, $\left.4 \mathrm{H}, \mathrm{C}_{5} \mathrm{H}_{4}\right), 4.07$ (s, 5H, $\left.\mathrm{C}_{5} \mathrm{H}_{5}\right), 4.51,4.64$ (2 br. s, $\left.2 \mathrm{H}, 4-\mathrm{H}\right)$, $7.08-7.18(\mathrm{~m}, 5 \mathrm{H}$, aromatic $\mathrm{H}) .-{ }^{13} \mathrm{C}$ NMR: $\delta=22.59\left(\mathrm{q}, \mathrm{CH}_{3}\right)$, 44.30 (d, C-1), 45.29 (t, C-2), 66.70, 66.92, 67.48, 67.57 (4 d, $\mathrm{C}_{5} \mathrm{H}_{4}$ ), $68.56\left(\mathrm{~d}, \mathrm{C}_{5} \mathrm{H}_{5}\right), 94.29$ (s, fc- $\left.\mathrm{C}_{i}\right), 112.52$ (t, C-4), $126.04\left(\mathrm{~d}, \mathrm{C}_{p}\right.$ ), 127.83, 127.97 ( $2 \mathrm{~d}, \mathrm{C}_{o}, \mathrm{C}_{m}$ ), 143.44, 144.87 (2 s, C $\mathrm{C}_{i}$-Aryl, C-3).

[1-(4-Methoxyphenyl)-3-methyl-3-butenyl]ferrocene (4d): Orange oil. $-{ }^{1} \mathrm{H}$ NMR: $\delta=1.68\left(\mathrm{~s}, 3 \mathrm{H}, 3-\mathrm{CH}_{3}\right), 2.53$ (dd, $J=11.2 /$ $13.6 \mathrm{~Hz}, 1 \mathrm{H}, 2-\mathrm{H}), 2.80(\mathrm{dd}, J=3.9 / 13.6 \mathrm{~Hz}, 1 \mathrm{H}, 2-\mathrm{H}), 3.74(\mathrm{~s}$, $\left.3 \mathrm{H}, \mathrm{OCH}_{3}\right), 3.77(\mathrm{dd}, J=4 / 11 \mathrm{~Hz}, 1 \mathrm{H}, 1-\mathrm{H}$, superimposed by the singlet at $\delta 3.74), 3.93,4.03,4.13\left(3 \mathrm{br} . \mathrm{s}, 3 \mathrm{H}, \mathrm{C}_{5} \mathrm{H}_{4}\right), 4.06(\mathrm{~s}, 6 \mathrm{H}$, $\mathrm{C}_{5} \mathrm{H}_{5}, \mathrm{C}_{5} \mathrm{H}_{4}$ ), 4.52, 4.65 (2 br. s, 2H, 4-H), 6.79, 7.07 (AA' BB' $^{\prime}$ system, $J_{\mathrm{AB}}=8.6 \mathrm{~Hz}, 4 \mathrm{H}$, aromatic $\left.\mathrm{H}\right) .-{ }^{13} \mathrm{C} \mathrm{NMR}: \delta=22.56$ (q, 3- $\left.\mathrm{CH}_{3}\right), 43.37$ (d, C-1), 45.32 (t, C-2), $55.05\left(\mathrm{q}, \mathrm{OCH}_{3}\right), 66.60$, 66.89, 67.41, $67.49\left(4 \mathrm{~d}, \mathrm{C}_{5} \mathrm{H}_{4}\right), 68.53\left(\mathrm{~d}, \mathrm{C}_{5} \mathrm{H}_{5}\right), 94.75\left(\mathrm{~s}, \mathrm{fc}-\mathrm{C}_{i}\right)$, 112.42 (t, C-4), 113.29 (d, $\mathrm{C}_{m}$ ), 128.64 (d, $\mathrm{C}_{o}$ ), 137.02 (s, $\mathrm{C}_{i}$-aryl), 143.53 (s, C-3), 157.70 (s, C-O).

4-Ferrocenyl-4-phenyl-2-butanone $(\mathbf{5 c})^{[33]}$ : Yellow powder, m.p. $89^{\circ} \mathrm{C}$ (ether) $\left(\right.$ ref. $\left.^{[33]} 96^{\circ} \mathrm{C}\right) .-{ }^{1} \mathrm{H}$ NMR: $\delta=2.00(\mathrm{~s}, 3 \mathrm{H}, 1-\mathrm{H})$, $3.05,3.11$ (AB part of an $\mathrm{ABM}$ system with $J_{\mathrm{AB}}=16.2, J_{\mathrm{AM}}=$ 9.6, $\left.J_{\mathrm{BM}}=4.7 \mathrm{~Hz}, 2 \mathrm{H}, 3-\mathrm{H}\right), 3.95$ (br. s, $\left.2 \mathrm{H}, \mathrm{C}_{5} \mathrm{H}_{4}\right), 4.06(\mathrm{~s}, 6 \mathrm{H}$, $\mathrm{C}_{5} \mathrm{H}_{5}, \mathrm{C}_{5} \mathrm{H}_{4}$ ), 4.10 (br. s, $1 \mathrm{H}, \mathrm{C}_{5} \mathrm{H}_{4}$ ), 4.27 (M part of an $\mathrm{ABM}$ system with $\left.J_{\mathrm{BM}}=4.7, J_{\mathrm{AM}}=9.6 \mathrm{~Hz}, 1 \mathrm{H}, 4-\mathrm{H}\right), 7.13-7.28(\mathrm{~m}$, $5 \mathrm{H}$, aromatic $\mathrm{H}$ ). $-{ }^{13} \mathrm{C}$ NMR: $\delta=30.95$ (q, C-1), 40.90 (d, C-4), 51.04 (t, C-3), 66.66, 67.18, $67.67\left(3 \mathrm{~d}, \mathrm{C}_{5} \mathrm{H}_{4}\right), 68.56\left(\mathrm{~d}, \mathrm{C}_{5} \mathrm{H}_{5}\right)$, $92.97\left(\mathrm{~s}, \mathrm{fc}_{-} \mathrm{C}_{i}\right), 126.38,127.61,128.24$ (3 d, aromatic C), 144.38 (s, $\mathrm{C}_{i}$-aryl), 207.20 (s, CO).

4-Ferrocenyl-4-(4-methoxyphenyl)-2-butanone (5d): Yellow powder, m.p. $90-91^{\circ} \mathrm{C}$ (ether). - ${ }^{1} \mathrm{H}$ NMR: $\delta=2.00$ (s, 3 H, 1-H), 3.02, 3.08 (AB part of an ABM system with $J_{\mathrm{AB}}=16.0, J_{\mathrm{AM}}=$ 9.9, $\left.J_{\mathrm{BM}}=4.6 \mathrm{~Hz}, 2 \mathrm{H}, 3-\mathrm{H}\right), 3.74\left(\mathrm{~s}, 3 \mathrm{H}, \mathrm{OCH}_{3}\right), 4.04,4.07(2 \mathrm{~m}$, $\left.4 \mathrm{H}, \mathrm{C}_{5} \mathrm{H}_{4}\right), 4.06\left(\mathrm{~s}, 5 \mathrm{H}, \mathrm{C}_{5} \mathrm{H}_{5}\right), 4.23(\mathrm{M}$ part of an ABM system with $J_{\mathrm{AM}}=9.9, J_{\mathrm{BM}}=4.6 \mathrm{~Hz}, 1 \mathrm{H}, 4-\mathrm{H}$ ), 6.79, 7.12 (AA'BB' system, $J_{\mathrm{AB}}=8.6 \mathrm{~Hz}, 4 \mathrm{H}$, aromatic $\mathrm{H}$ ). $-{ }^{13} \mathrm{C} \mathrm{NMR}: \delta=30.89$ (q, $\mathrm{C}-1), 40.21$ (d, C-4), 51.20 (t, C-3), $55.10\left(\mathrm{q}, \mathrm{OCH}_{3}\right), 66.56,67.19$, 67.61, $67.66\left(4 \mathrm{~d}, \mathrm{C}_{5} \mathrm{H}_{4}\right), 68.52\left(\mathrm{~d}, \mathrm{C}_{5} \mathrm{H}_{5}\right), 93.41\left(\mathrm{~s}, \mathrm{fc}-\mathrm{C}_{i}\right), 113.61$ $\left(\mathrm{d}, \mathrm{C}_{m}\right), 128.54$ (d, $\left.\mathrm{C}_{o}\right), 136.56\left(\mathrm{~s}, \mathrm{C}_{i}\right.$-aryl), $158.01(\mathrm{~s}, \mathrm{C}-\mathrm{O}), 207.26$ (s, CO).

2-(Ferrocenylphenylmethyl) cyclopentanone (6c): Mixture of diastereomers $(\approx 3: 1)$, orange powder. $-{ }^{1} \mathrm{H}$ NMR: $\delta=1.35-1.83(\mathrm{~m}$, $\left.4 \mathrm{H}, 2 \mathrm{CH}_{2}\right), 2.04-2.22\left(\mathrm{~m}, 2 \mathrm{H}, \mathrm{CH}_{2}\right), 2.34-2.41,2.88-2.95(2 \mathrm{~m}$, $1 \mathrm{H}, 2-\mathrm{H}), 3.81,4.05\left(2 \mathrm{~s}, 5 \mathrm{H}, \mathrm{C}_{5} \mathrm{H}_{5}\right), 3.85,3.93,3.98,4.07,4.14(5$ $\left.\mathrm{m}_{\mathrm{c}}, 4 \mathrm{H}, \mathrm{C}_{5} \mathrm{H}_{4}\right), 4.33,4.63(2 \mathrm{~d}, J=3.0 / 2.2 \mathrm{~Hz}, 1 \mathrm{H}, \mathrm{CH})$, 6.84-6.87, 7.03-7.11, 7.17-7.37 (3 m, 5H, aromatic $\mathrm{H}) .-{ }^{13} \mathrm{C}$ NMR: $\delta=20.38,20.66,26.18,38.44,38.65\left(5 \mathrm{t}, \mathrm{CH}_{2}\right), 44.16$, $45.60,54.48,56.20$ (4 d, CH, C-2), 66.87, 67.39, 67.51, 67.63, 68.00, $68.22,68.45,68.52,68.66,69.09\left(10 \mathrm{~d}, \mathrm{C}_{5} \mathrm{H}_{5}, \mathrm{C}_{5} \mathrm{H}_{4}\right), 89.26,91.98$ $\left(2 \mathrm{~s}, \mathrm{fc}-\mathrm{C}_{i}\right), 126.15,126.41,127.81,128.10,128.67$ (5 d, aromatic C), 142.85, 143.49 (2 s, $\mathrm{C}_{i}$-aryl), 219.60, 220.13 (2 s, CO).

2-[Ferrocenyl(4-methoxyphenyl)methyl]cyclopentanone (6d): Mixture of diastereomers $(\approx 1: 4)$, orange oil. $-{ }^{1} \mathrm{H}$ NMR: $\delta=$ 1.45-1.80 (m, 4 H, 2 $\left.\mathrm{CH}_{2}\right), 2.05-2.30\left(\mathrm{~m}, 2 \mathrm{H}, \mathrm{CH}_{2}\right), 2.44,2.95$ (2 $\left.\mathrm{m}_{\mathrm{c}}, 1 \mathrm{H}, 2-\mathrm{H}\right), 3.73,3.83\left(2 \mathrm{~s}, \mathrm{OCH}_{3}\right), 3.93,4.13\left(2 \mathrm{~s}, \mathrm{C}_{5} \mathrm{H}_{5}\right)$, 3.98-4.21 (m, $\left.\mathrm{C}_{5} \mathrm{H}_{4}\right), 4.36,4.65(2 \mathrm{~d}, J=2.8 / 1.4 \mathrm{~Hz}, 1 \mathrm{H}, \mathrm{fcArCH})$, $6.70,6.86\left(\mathrm{AA}^{\prime} \mathrm{BB}^{\prime}\right.$ system, $J_{\mathrm{AB}}=8.6 \mathrm{~Hz}$, aromatic $\left.\mathrm{H}\right), 6.90,7.33$ 
Table 2. Kinetics of the reactions of ferrocenylmethylium ions with nucleophiles ${ }^{\text {[a] }}$

\begin{tabular}{|c|c|c|c|c|c|c|c|c|c|c|c|}
\hline \multicolumn{4}{|c|}{$\begin{array}{l}\text { Ferrocenylmethylium } 2 a\left[(8.72-14.5] \times 10^{-5} \mathrm{~mol}\right. \\
\text { l-1) and Dimethylphenylsilane } 9\end{array}$} & \multicolumn{4}{|c|}{$\begin{array}{l}\text { Ferrocenylmethylium } 2 a\left((7.31-8.59) \times 10^{-5} \mathrm{~mol}\right. \\
\left.\left.l^{-1}\right)\right] \text { and Triphenylsilane } 10\end{array}$} & \multicolumn{4}{|c|}{$\begin{array}{l}\text { Ferrocenylethylium } 2 b\left[(1.45-1.88) \times 10^{-3} \mathrm{~mol}\right. \\
\left.\left.l^{-1}\right)\right] \text { and Methallyltrimethylsilane } 4\end{array}$} \\
\hline$T^{\circ} \mathrm{C}$ & {$[9] / \mathrm{mol} \mathrm{l}^{-1}$} & $\begin{array}{c}\text { Conversion/ } \\
\%[b]\end{array}$ & $\begin{array}{c}k_{2} / \\
1 \mathrm{~mol}^{-1} \mathrm{~s}^{-1}\end{array}$ & $T^{\circ} \mathrm{C}$ & {$[10] / \mathrm{mol} \mathrm{l}^{-1}$} & $\begin{array}{l}\text { Conversion/ } \\
\%[b]\end{array}$ & $\begin{array}{c}k_{2} / \\
1 \mathrm{~mol}^{-1} \mathrm{~s}^{-1}\end{array}$ & $T /{ }^{\circ} \mathrm{C}$ & {$[4] / \mathrm{mol} \mathrm{l}^{-1}$} & $\begin{array}{c}\text { Conversion/ } \\
\%[b]\end{array}$ & $\frac{k_{2} /}{1 \mathrm{~mol}^{-1} \mathrm{~s}^{-1}}$ \\
\hline-0.5 & $3.09 \times 10^{-3}$ & 53 & 2.55 & 21.1 & $1.44 \times 10^{-3}$ & 46 & 1.17 & -20.8 & $2.18 \times 10^{-2}$ & 67 & 6.77 \\
\hline-9.5 & $1.78 \times 10^{-3}$ & 86 & 1.18 & 5.1 & $2.01 \times 10^{-3}$ & 36 & $3.5 \times 10^{-1}$ & -39.8 & $7.85 \times 10^{-2}$ & 64 & 1.73 \\
\hline-11.3 & $3.20 \times 10^{-3}$ & 90 & 1.09 & 0.0 & $2.99 \times 10^{-3}$ & 69 & $2.1 \times 10^{-1}$ & -46.5 & $7.77 \times 10^{-2}$ & 97 & $8.7 \times 10^{-1}$ \\
\hline-30.7 & $3.25 \times 10^{-3}$ & 94 & $1.70 \times 10^{-1}$ & -10.2 & $2.55 \times 10^{-3}$ & 43 & $8.0 \times 10^{-2}$ & -47.2 & $2.45 \times 10^{-2}$ & 66 & 1.07 \\
\hline \multirow{2}{*}{-51.3} & $9.49 \times 19^{-3}$ & 33 & $1.87 \times 10^{-2}$ & & & & & -57.3 & $1.89 \times 10^{-2}$ & 56 & $4.6 \times 10^{-1}$ \\
\hline & & & & & & & & -66.6 & $8.73 \times 10^{-3}$ & 72 & $2.0 \times 10^{-1}$ \\
\hline \multicolumn{4}{|c|}{$\begin{array}{l}\text { Ferrocenylethylium } 2 b\left[(1.50 \cdot 1.75) \times 10^{-3} \mathrm{~mol}\right. \\
\left.l^{-1}\right] \text { and Dimethylphenylsilane } 9\end{array}$} & $\begin{array}{l}\text { Ferrocen } \\
10^{-4} \mathrm{~mol} \\
6\end{array}$ & $\begin{array}{l}\text { lphenylmethyl } \\
\left.\left.l^{-1}\right)\right] \text { and Trin }\end{array}$ & $\begin{array}{l}2 c \quad I(1) \\
\text { methylsiloxycy }\end{array}$ & $\begin{array}{l}1.74-2.00) x \\
\text { yclopentene }\end{array}$ & \multicolumn{4}{|c|}{$\begin{array}{l}\text { Ferrocenylphenylmethylium } 2 c \quad[(3.57-5.04) x \\
\left.10^{-4} \text { mol } 1^{-1}\right) \text { and Trimethylsiloxycyclohexene } 7\end{array}$} \\
\hline$T \rho \mathrm{C}$ & {$[9] / \mathrm{mol} \mathrm{l}^{-1}$} & $\begin{array}{c}\text { Conversion/ } \\
\%[b]\end{array}$ & $\begin{array}{c}k_{2} / \\
1 \mathrm{~mol}^{-1} \mathrm{~s}^{-1}\end{array}$ & $T^{P} \mathrm{C}$ & {$[6] / \mathrm{mol} \mathrm{l}^{-1}$} & $\begin{array}{l}\text { Conversion/ } \\
\%[\mathbf{b}]\end{array}$ & $\begin{array}{c}k_{2} / \\
1 \mathrm{~mol}^{-1} \mathrm{~s}^{-1}\end{array}$ & $T /{ }^{\circ} \mathrm{C}$ & {$[7] / \mathrm{mol} \mathrm{I}^{-1}$} & $\begin{array}{c}\text { Conversion/ } \\
\%[b]\end{array}$ & $\frac{k_{2} l}{1 \mathrm{~mol}^{-1} \mathrm{~s}^{-1}}$ \\
\hline-0.4 & $2.27 \times 10^{-2}$ & 62 & $4.62 \times 10^{-1}$ & -51.8 & $2.05 \times 10^{-3}$ & 83 & 137.1 & -40.0 & $6.48 \times 10^{-3}$ & 44 & 20.42 \\
\hline-9.7 & $2.57 \times 10^{-2}$ & 49 & $2.13 \times 10^{-1}$ & -61.8 & $2.36 \times 10^{-3}$ & 84 & 74.6 & -50.8 & $4.87 \times 10^{-3}$ & 26 & 10.31 \\
\hline-20.5 & $2.21 \times 10^{-2}$ & 69 & $1.26 \times 10^{-1}$ & -71.7 & $2.20 \times 10^{-3}$ & 89 & 38.1 & -68.5 & $5.02 \times 10^{-3}$ & 36 & 2.87 \\
\hline-20.5 & $4.80 \times 10^{-2}$ & 72 & $9.32 \times 10^{-2}$ & & & & & -69.1 & $7.47 \times 10^{-3}$ & 67 & 2.87 \\
\hline-40.3 & $2.67 \times 19^{-2}$ & 71 & $1.32 \times 10^{-2}$ & & & & & & & & \\
\hline-60.4 & $2.70 \times 10^{-2}$ & 61 & $1.22 \times 10^{-3}$ & & & & & & & & \\
\hline \multicolumn{4}{|c|}{$\begin{array}{l}\text { Ferrocenylphenylmethylium } 2 c[(2.07-2.53) x \\
\left.\left.10^{-4} \text { mol } t^{-1}\right)\right] \text { and Trimethylsiloxypropene } 5\end{array}$} & \multicolumn{4}{|c|}{$\begin{array}{l}\text { Ferrocenylphenylmethylium } 2 c][(3.01-5.16) x \\
\left.\left.10^{-4} \text { mol } l^{-1}\right)\right] \text { and Methallyltrimethylsilane } 4\end{array}$} & \multicolumn{4}{|c|}{$\begin{array}{l}\text { Ferrocenylphenylmethylium } 2 c[(2.33-2.80) x \\
\left.\left.10^{-4} \text { mol } l^{-1}\right)\right] \text { and Dimethylphenylsilane } 9\end{array}$} \\
\hline$T^{\circ} \mathrm{C}$ & {$[5] / \mathrm{mol} \mathrm{l}^{-1}$} & $\begin{array}{l}\text { Conversion/ } \\
\%[b]\end{array}$ & $\begin{array}{c}k_{2} / \\
1 \mathrm{~mol}^{-1} \mathrm{~s}^{-1}\end{array}$ & $T P C$ & {$[4] / \mathrm{mol} \mathrm{I}^{-1}$} & $\begin{array}{l}\text { Conversion/ } \\
\%[b]\end{array}$ & $\begin{array}{c}k_{2} / \\
1 \mathrm{~mol}^{-1} \mathrm{~s}^{-1}\end{array}$ & $T / \mathrm{C}$ & {$[9] / \mathrm{mol} \mathrm{l}^{-1}$} & $\begin{array}{c}\text { Conversion/ } \\
\%[b]\end{array}$ & $\frac{k_{2} /}{1 \mathrm{~mol}^{-1} \mathrm{~s}^{-1}}$ \\
\hline-20.9 & $2.06 \times 10^{-3}$ & 67 & 44.0 & -9.8 & $1.78 \times 10^{-3}$ & 52 & 11.0 & 19.5 & $3.97 \times 10^{-3}$ & 80 & 1.59 \\
\hline-31.2 & $2.02 \times 10^{-3}$ & 76 & 16.2 & -29.3 & $4.17 \times 10^{-3}$ & 90 & 5.60 & -0.5 & $6.28 \times 10^{-3}$ & 82 & 0.33 \\
\hline-51.8 & $2.56 \times 10^{-3}$ & 49 & 3.04 & -41.2 & $5.72 \times 10^{-3}$ & 78 & 1.59 & -5.5 & $8.83 \times 10^{-3}$ & 32 & 0.23 \\
\hline \multirow{3}{*}{-71.6} & $2.10 \times 10^{-3}$ & 79 & 0.77 & -49.6 & $8.23 \times 10^{-3}$ & 82 & 1.65 & -10.5 & $4.76 \times 10^{-3}$ & 62 & 0.15 \\
\hline & & & & -62.0 & $6.06 \times 10^{-3}$ & 95 & 0.34 & & & & \\
\hline & & & & -69.1 & $6.10 \times 10^{-3}$ & 92 & 0.24 & & & & \\
\hline \multicolumn{4}{|c|}{$\begin{array}{l}\text { Ferrocenylphenylmethylium } 2 c \quad[(2.79-5.1 x \\
\left.\left.10^{-4} \text { mol } l^{-1}\right)\right] \text { and Allyltriphenylstannane } 3\end{array}$} & \multicolumn{4}{|c|}{$\begin{array}{l}\text { Ferrocenyl-(p-anisyl)-methylium } 2 d((1.67-3.73) \\
\left.\left.x 10^{-4} \text { mol } l^{-1}\right)\right] \text { and Trimethylsiloxypropene } 5\end{array}$} & \multicolumn{4}{|c|}{$\begin{array}{l}\text { Ferrocenyl-(p-anisyl)-methylium } 2 d] \text { [(2.55-3.96) } \\
\left.\left.x 10^{-4} \text { mol } l^{-1}\right)\right] \text { and Methallyltrimethylsilane } 4\end{array}$} \\
\hline$T^{p} \mathrm{C}$ & {$[3] / \mathrm{mol} \mathrm{I}^{-1}$} & $\begin{array}{l}\text { Conversion/ } \\
\%[b]\end{array}$ & $\begin{array}{c}k_{2} / \\
1 \mathrm{~mol}^{-1} \mathrm{~s}^{-1}\end{array}$ & $T^{\circ} \mathrm{C}$ & {$[5] / \mathrm{mol} \mathrm{I}^{-1}$} & $\begin{array}{c}\text { Conversion/ } \\
\%[b]\end{array}$ & $\begin{array}{c}k_{2} / \\
1 \mathrm{~mol}^{-1} \mathrm{~s}^{-1}\end{array}$ & $T^{\circ} \mathrm{C}$ & {$[4] / \mathrm{mol} \mathrm{l}^{-1}$} & $\begin{array}{c}\text { Conversion/ } \\
\%[b]\end{array}$ & a/ $\begin{array}{c}k_{2} / \\
1 \mathrm{~mol}^{-1} \mathrm{~s}^{-1}\end{array}$ \\
\hline 23.1 & $4.63 \times 10^{-3}$ & 50 & 2.59 & -23.0 & $6.33 \times 10^{-3}$ & 78 & 18.4 & -11.2 & $6.91 \times 10^{-3}$ & 51 & 5.57 \\
\hline 2.0 & $1.97 \times 10^{-3}$ & 63 & 0.81 & -30.2 & $9.61 \times 10^{-3}$ & 74 & 15.4 & -20.6 & $5.81 \times 10^{-3}$ & 43 & 3.56 \\
\hline \multirow[t]{6}{*}{-5.3} & $3.08 \times 10^{-3}$ & 88 & 0.60 & -31.5 & $9.01 \times 10^{-3}$ & 32 & 13.1 & -20.9 & $4.51 \times 10^{-3}$ & 18 & 3.26 \\
\hline & & & & -39.1 & $7.55 \times 10^{-3}$ & 93 & 5.04 & -30.5 & $7.24 \times 10^{-3}$ & 49 & 1.83 \\
\hline & & & & -50.8 & $7.53 \times 10^{-3}$ & 95 & 3.81 & -49.5 & $6.83 \times 10^{-3}$ & 60 & 0.56 \\
\hline & & & & -59.5 & $7.52 \times 10^{-3}$ & 92 & 0.97 & & & & \\
\hline & & & & -60.2 & $3.24 \times 10^{-3}$ & 75 & 1.03 & & & & \\
\hline & & & & -60.6 & $8.73 \times 10^{-3}$ & 72 & 1.26 & & & & \\
\hline \multicolumn{4}{|c|}{$\begin{array}{l}\text { Ferrocenyl-(p-anisyl)-methylium } 2 d[(3.11-3.82) \\
\left.\left.x 10^{-4} \text { mol } l^{-1}\right)\right] \text { and Dimethylphenylsilane } 9\end{array}$} & \multicolumn{4}{|c|}{$\begin{array}{l}\text { Diferrocenylmethylium } 2 \mathrm{e}-\mathrm{BF}_{4}\left(3.46 \times 10^{-4} \mathrm{~mol}\right. \\
\left.l^{-1}\right) \text { and Trimethylsiloxycyclohexene } 7\end{array}$} & \multicolumn{4}{|c|}{$\begin{array}{l}\text { Diferrocenylmethylium 2e-BF } 4((3.05-3.51) x \\
\left.\left.10^{-4} \text { mol } t^{-1}\right)\right] \text { and Trimethylsiloxycyclopentene } 6\end{array}$} \\
\hline$T P^{\circ} \mathrm{C}$ & {$[9] / \mathrm{mol} \mathrm{I}^{-1}$} & $\begin{array}{c}\text { Conversion/ } \\
\%[b]\end{array}$ & $\frac{k_{2} /}{1 \mathrm{~mol}^{-1} \mathrm{~s}^{-1}}$ & $T^{\circ} \mathrm{C}$ & {$[7] / \mathrm{mol} \mathrm{l}^{-1}$} & $\begin{array}{c}\text { Conversion/ } \\
\%[\mathrm{~b}]\end{array}$ & $\begin{array}{c}k_{2} ! \\
\mathrm{mol}^{-1} \mathrm{~s}^{-1}\end{array}$ & $T / \mathrm{C}$ & {$[6] / \mathrm{mol} \mathrm{l}^{-1}$} & $\begin{array}{c}\text { Conversion/ } \\
\%[\mathrm{~b}]\end{array}$ & $\begin{array}{c}k_{2} \mid \\
\mid \mathrm{mol}^{-1} \mathrm{~s}^{-1}\end{array}$ \\
\hline 25.3 & $7.65 \times 10^{-3}$ & 57 & 1.21 & 20.0 & $2.11 \times 10^{-2}$ & 74 & $1.31 \times 10^{-3}$ & 20.0 & $5.06 \times 10^{-3}$ & 88 & $3.05 \times 10^{-2}$ \\
\hline-0.2 & $9.12 \times 10^{-3}$ & 69 & 0.20 & 20.0 & $9.27 \times 10^{-3}$ & 41 & $1.11 \times 10^{-3}$ & 20.0 & $1.01 \times 10^{-2}$ & 81 & $2.94 \times 10^{-2}$ \\
\hline-0.3 & $4.32 \times 10^{-3}$ & 89 & 0.24 & & & & & 5.0 & $1.05 \times 10^{-2}$ & 83 & $1.36 \times 10^{-2}$ \\
\hline-9.6 & $8.80 \times 10^{-3}$ & 53 & $8.98 \times 10^{-2}$ & & & & & -14.4 & $1.03 \times 10^{-2}$ & 65 & $3.77 \times 10^{-3}$ \\
\hline-20.5 & $9.36 \times 10^{-3}$ & 69 & $3.43 \times 10^{-2}$ & & & & & -14.3 & $1.16 \times 10^{-2}$ & 93 & $3.72 \times 10^{-3}$ \\
\hline-40.3 & $7.91 \times 10^{-3}$ & 85 & $4.79 \times 10^{-3}$ & & & & & & & & \\
\hline \multicolumn{4}{|c|}{$\begin{array}{l}\text { Diferrocenylmethylium } 2 e-B F_{4} \quad[(2.96-3.82) \\
\left.\left.x 10^{-4} \text { mol l }^{-1}\right)\right] \text { and Sily keteneacetal } 8\end{array}$} & $\begin{array}{l}\text { Diferroc } \\
x 10^{-4} \mathrm{mc}\end{array}$ & enylmethylium & $\begin{array}{l}\text { 2e-OTf } \\
\text { ibutylstannane }\end{array}$ & $\begin{array}{l}{[(2.44-2.91)} \\
11\end{array}$ & & & & \\
\hline$T^{\circ} \mathrm{C}$ & {$\left[8 \mathrm{j} / \mathrm{mol} \mathrm{l}^{-1}\right.$} & $\begin{array}{l}\text { Conversion/ } \\
\%[\mathbf{b}]\end{array}$ & $\begin{array}{c}k_{2} / \\
l \mathrm{~mol}^{-1} \mathrm{~s}^{-1}\end{array}$ & $T^{\rho} \mathrm{C}$ & {$[11] / \mathrm{mol} \mathrm{I}^{-1}$} & $\begin{array}{l}\text { Conversion/ } \\
\%[\text { b] }\end{array}$ & $\begin{array}{c}k_{2} / \\
\mathrm{mol}^{-1} \mathrm{~s}^{-1}\end{array}$ & & & & \\
\hline 20.0 & $9.69 \times 10^{-3}$ & 93 & $5.46 \times 10^{-1}$ & 20.0 & $7.32 \times 10^{-3}$ & 98 & 3.54 & & & & \\
\hline 20.0 & $4.82 \times 10^{-3}$ & 53 & $4.90 \times 10^{-1}$ & 20.0 & $3.11 \times 10^{-3}$ & 96 & 3.47 & & & & \\
\hline 10.0 & $4.47 \times 10^{-3}$ & 94 & $3.36 \times 10^{-1}$ & -4.8 & $3.70 \times 10^{-3}$ & 98 & $7.38 \times 10^{-1}$ & & & & \\
\hline 3.7 & $8.61 \times 10^{-3}$ & 88 & $2.83 \times 10^{-1}$ & -9.6 & $7.10 \times 10^{-3}$ & 96 & $4.87 \times 10^{-1}$ & & & & \\
\hline-18.1 & $9.59 \times 10^{-3}$ & 94 & $7.76 \times 10^{-2}$ & -29.2 & $7.02 \times 10^{-3}$ & 94 & $1.17 \times 10^{-1}$ & & & & \\
\hline-26.5 & $1.01 \times 10^{-2}$ & 93 & $5.13 \times 10^{-2}$ & & & & & & & & \\
\hline
\end{tabular}

[a] The reactions of $\mathbf{2 a}$ were followed conductometrically, the rate constants of $\mathbf{2 b}-\mathbf{e}$ were determined photometrically. - [b] Range evaluated for the determination of $k_{2}$. 
(AA'BB' system, $J_{\mathrm{AB}}=8.6 \mathrm{~Hz}$, aromatic H). ${ }^{13} \mathrm{C}$ NMR: $\delta=$ 20.46, 20.74, 26.15, 26.23, 38.57, $38.79\left(6 \mathrm{t}, \mathrm{CH}_{2}\right), 43.50,44.84$ (2 d, C-2), 54.60, 55.10, 55.22, $56.40\left(2 \mathrm{q}, \mathrm{OCH}_{3}, 2 \mathrm{~d}, \mathrm{CH}\right), 66.94$, 67.46, 67.67, 68.06, 68.41, 68.78, $69.14\left(7 \mathrm{~d}, \mathrm{C}_{5} \mathrm{H}_{5}, \mathrm{C}_{5} \mathrm{H}_{4}\right), 89.33$, $92.47\left(2 \mathrm{~s}, \mathrm{fc}-\mathrm{C}_{i}\right), 113.19,113.44\left(2 \mathrm{~d}, \mathrm{C}_{m}\right), 129.69\left(\mathrm{~d}, \mathrm{C}_{o}\right), 135.07$, 135.85 ( $2 \mathrm{~s}, \mathrm{C}_{i}$-aryl), 157.89, $158.05(2 \mathrm{~s}, \mathrm{C}-\mathrm{O}), 219.91,220.48(2$ $\mathrm{s}, \mathrm{CO})$.

2-[Bis(ferrocenyl) methyl]cyclopentanone (6e): Orange powder, m.p. $145.5^{\circ} \mathrm{C}$ (ether). $-{ }^{1} \mathrm{H}$ NMR: $\delta=1.35-2.35\left(\mathrm{~m}, 6 \mathrm{H}, \mathbf{C H}_{2}\right)$, $3.02\left(\mathrm{~m}_{\mathrm{c}}, 1 \mathrm{H}, 2-\mathrm{H}\right), 4.03,4.15\left(2 \mathrm{~s}, 10 \mathrm{H}, \mathrm{C}_{5} \mathrm{H}_{5}\right), 4.30(\mathrm{~d}, J=1.6$ $\left.\mathrm{Hz}, 1 \mathrm{H}, \mathrm{fc}_{2} \mathrm{CH}\right), 3.50,3.79,3.94,3.98,4.05,4.20,4.46(7 \mathrm{~m}, 8 \mathrm{H}$, $\mathrm{C}_{5} \mathrm{H}_{4}$ ). ${ }^{13} \mathrm{C}$ NMR: $\delta=20.68,25.90,38.63\left(3 \mathrm{t}, \mathrm{CH}_{2}\right), 38.45$ (d, $\left.\mathrm{fc}_{2} \mathrm{CH}\right), 56.54$ (d, C-2), 68.36, 68.66 (2 d, $\left.\mathrm{C}_{5} \mathrm{H}_{5}\right), 66.27,66.42,66.60$, $67.17,67.35,67.41,69.90\left(7 \mathrm{~d}, \mathrm{C}_{5} \mathrm{H}_{4}\right), 91.75,92.18\left(2 \mathrm{~s}, \mathrm{C}_{i}\right), 220.9$ (s, CO).

2-(1-Ferrocenylethyl)cyclohexanone (7b): Mixture of diastereomers $(\approx 1: 2.5)$, orange powder ${ }^{[34]}$. ${ }^{1} \mathrm{H}$ NMR: $\delta=1.20,1.30(2$ d, $\left.J=7 \mathrm{~Hz}, 3 \mathrm{H}, \mathrm{CH}_{3}\right), 1.43-2.42(\mathrm{~m}, 9 \mathrm{H}), 3.09,3.29\left(2 \mathrm{~m}_{\mathrm{c}}, 1 \mathrm{H}\right)$, 4.04-4.23 (m, 9 H, $\left.\mathrm{C}_{5} \mathrm{H}_{5}, \mathrm{C}_{5} \mathrm{H}_{4}\right)$.

Methyl 3,3-Bis(ferrocenyl)-2,2-dimethylpropionate (8e): Orange powder, m.p. $103-105^{\circ} \mathrm{C}$ (hexane). $-{ }^{1} \mathrm{H}$ NMR: $\delta=1.19$ (s, $6 \mathrm{H}$, $\left.\mathrm{CH}_{3}\right), 3.78\left(\mathrm{~s}, 3 \mathrm{H}, \mathrm{OCH}_{3}\right), 3.91(\mathrm{~s}, 1 \mathrm{H}, 3-\mathrm{H}), 4.00\left(\mathrm{~s}, 10 \mathrm{H}, \mathrm{C}_{5} \mathrm{H}_{5}\right)$, $4.04\left(\mathrm{~m}_{\mathrm{c}}, 2 \mathrm{H}, \mathrm{C}_{5} \mathrm{H}_{4}\right), 4.11-4.13\left(\mathrm{~m}, 6 \mathrm{H}, \mathrm{C}_{5} \mathrm{H}_{4}\right) .-{ }^{13} \mathrm{C} \mathrm{NMR}: \delta=$ 24.03 (q, $\mathrm{CH}_{3}$ ), 43.99 (d, C-3), 47.92 (s, C-2), 51.84 (q, $\mathrm{OCH}_{3}$ ), 67.30, 69.32, $70.42\left(3 \mathrm{~d}, \mathrm{C}_{5} \mathrm{H}_{4}\right), 68.81\left(\mathrm{~d}, \mathrm{C}_{5} \mathrm{H}_{5}\right), 91.83\left(\mathrm{~s}, \mathrm{fc}-\mathrm{C}_{i}\right)$, 178.61 (s, CO).

Methylferrocene (9a): Orange oil ${ }^{[35]}$. - ${ }^{1} \mathrm{H}$ NMR: $\delta=1.89(\mathrm{~s}$, $\left.3 \mathrm{H}, \mathrm{CH}_{3}\right), 3.94,3.98\left(2 \mathrm{~m}_{\mathrm{c}}, 4 \mathrm{H}, \mathrm{C}_{5} \mathrm{H}_{4}\right), 4.01\left(\mathrm{~s}, 5 \mathrm{H}, \mathrm{C}_{5} \mathrm{H}_{5}\right)$.

(4-Methoxybenzyl)ferrocene $(9 \mathrm{~d})^{[31,36]}$ : Orange needles from ether, m.p. $71.5^{\circ} \mathrm{C}$ (ref. ${ }^{[31]} 72-75^{\circ} \mathrm{C}$ ). $-{ }^{1} \mathrm{H}$ NMR: $\delta=3.63(\mathrm{~s}, 2 \mathrm{H}$, $\mathrm{CH}_{2}$ ), 3.77 (s, $\left.3 \mathrm{H}, \mathrm{OCH}_{3}\right), 4.07\left(\mathrm{~s}, 4 \mathrm{H}, \mathrm{C}_{5} \mathrm{H}_{4}\right), 4.11\left(\mathrm{~s}, 5 \mathrm{H}, \mathrm{C}_{5} \mathrm{H}_{5}\right.$ ), $6.80,7.09$ ( AA' $^{\prime} \mathrm{BB}^{\prime}$ system, $J_{\mathrm{AB}}=8.6 \mathrm{~Hz}, 4 \mathrm{H}$, aromatic $\mathrm{H}$ ).

Kinetic Investigations (Table 2): The consumption of the ferrocenylmethylium ions was determined conductometrically (2a) or photometrically $(\mathbf{2 b}-\mathbf{e})$ by using fiber optics and the working station described in ref. ${ }^{[21]}$. Calibration curves, i.e. the correlation between absorbance (or conductivity in the case of $\mathbf{2 a}$ ) and concentration of the ferrocenylmethylium ions $2 \mathbf{a}-\mathbf{d}$, were obtained by adding the acetates $\mathbf{1 a}-\mathbf{d}$ in portions to a solution of $\mathrm{Me}_{3} \mathrm{SiOTf}$ in $\mathrm{CH}_{2} \mathrm{Cl}_{2}$ and determination of the absorbance after completion of the ionization. In the case of $2 \mathrm{e}$ the calibration curve was obtained by determination of the absorbance of solutions of $2 \mathrm{e}-\mathrm{CF}_{3} \mathrm{SO}_{3}^{-}$or $2 \mathbf{e}-\mathrm{BF}_{4}^{-}$at different concentrations.

Dedicated to Professor Dr. W. Tochtermann on the occasion of his 60 th birthday.

[1] [la] C. G. Swain, C. B. Scott, J. Am. Chem. Soc. 1953, 75, 141-147. - [1b] J. O. Edwards, J. Am. Chem. Soc. 1954, 76, 1540-1547. - [1c] J. O. Edwards, J. Am. Chem. Soc. 1956, 78, 1819-1820. - [1d] J. F. Bunnett, Ann. Rev. Phys. Chem. 1963, 14, 271-290. - [1e] R. G. Pearson, H. Sobel, J. Songstad, J. Am. Chem. Soc. 1968, 90, 319-326. - [11] A. J. Parker, Chem. Rev. 1969, 69, 1-32. - ${ }^{1 \mathrm{lg}]} \mathrm{J}$. M. Harris, S. P. McManus, Nucleophilicity - Advances in Chemistry Series, Nr. 215, ACS, Washington DC, 1987. - [1h] L. A. P. Kane-Maguire, E. D. Honig, D. A. Sweigart, Chem. Rev. 1984, 84, 525-543. - [ii] C. D. Ritchie, Can. J. Chem. 1986, 64, 2239-2250. - [lk] C. D. Ritchie, J. Am. Chem. Soc. 1975, 97, 1170-1179.

[2] H. Mayr, Angew. Chem. 1990, 102, 1415-1428; Angew. Chem. Int. Ed. Engl. 1990, 29, 1371-1384.

[3] H. Mayr, R. Schneider, B. Irrgang, C. Schade, J. Am. Chem. Soc. 1990, 112, 4454-4459.

[4] G. Hagen, H. Mayr, J. Am. Chem. Soc. 1991, 113, 4954-4961.

[5] H. Mayr, J. Bartl, G. Hagen, Angew. Chem. 1992, 104, 1689-1691; Angew. Chem. Int. Ed. Engl. 1992, 31, 1613-1615.

[6] H. Mayr, N. Basso, Angew. Chem. 1992, 104, 1103-1105; Angew. Chem. Int. Ed. Engl. 1992, 31, 1046-1048.
[7] H. Mayr, N. Basso, G. Hagen, J. Am. Chem. Soc. 1992, 114, 3060-3066.

[8] H. Mayr, M. Patz, Angew. Chem. 1994, 106, 990-1010; Angew. Chem. Int. Ed. Engl. 1994, 33, 938-957.

[9] H. Mayr, K.-H. Müller, D. Rau, Angew. Chem. 1993, 105, 1732-1734; Angew. Chem. Int. Ed. Engl. 1993, 32, 1630-1632.

[10] [10a] T. J. Kealy, P. L. Pauson, Nature 1951, 168, 1039-1040. [10b] S. A. Miller, J. A. Tebboth, J. F. Tremaine, J. Chem. Soc 1952, 632-635. - [10c] E. O. Fischer, W. Pfab, Z. Naturforsch., Teil $B$ 1952, 7, 377-379. - [10d] G. Wilkinson, M. Rosenblum, M. C. Whiting, R. B. Woodward, J. Am. Chem. Soc. 1952, 74, 2125-2126.

[11] C. A. Bunton, N. Carrasco, F. Davoudzadeh, W. E. Watts, J. Chem. Soc., Perkin Trans. 2, 1980, 1520-1528.

[12] [12a] J. H. Richards, E. A. Hill, J. Am. Chem. Soc. 1959, 81, 3484-3485. - ${ }^{[12 b]}$ G. Cerichelli, B. Floris, G. Ortaggi, J. Organomet. Chem. 1974, 78, 241-252. - [12c] C. Lo Sterzo, G. Ortaggi, Tetrahedron 1984, 40, 593-599.

[13] C. A. Bunton, N. Carrasco, W. E. Watts, J. Organomet. Chem. 1977, 131, C21-C25.

[14] [14a] M. Cais, J. J. Dannenberg, A. Eisenstadt, M. I. Levenberg, J. H. Richards, Tetrahedron Lett. 1966, 1695-1701. - [14b] G. Neshvad, R. M. G. Roberts, J. Silver, J. Organomet. Chem. 1982, 236, 237-244. - [14c] V. N. Postnov, E. I. Klimova, N. N. Meleshonkova, M. Martines, Dokl. Chem. (Engl. Transl.) 1992 $128-131 .-{ }^{[14 d]}$ C. Cordier, M. Gruselle, J. Vaissermann, L. L. Troitskaya, V. I. Bakhmutov, V. I. Sokolov, G. Jauoen, Organometallics 1992, 11, 3825-3832. - ${ }^{[14 \mathrm{e}]} \mathrm{S}$. Braun, T. S. Abram, W. E. Watts, J. Organomet, Chem. 1975, 97, 429-441.

[15] L. I. Kazakova, N. M. Loim, E. G. Perevalova, Z. N. Parnes, J. Org. Chem. USSR (Engl. Transl.) 1974, 2294-2297.

[16] [16a] C. A. Bunton, W. E. Watts, Tetrahedron Lett. 1977, 2049-2052. - ${ }^{[16 b]}$ C. A. Bunton, N. Carrasco, N. Cully, W. E. Watts, J. Chem. Soc., Perkin Trans. 2, 1980, 1859-1867.

[17] [17a] D. Schinzer, Synthesis 1988, 263-273. - [17b] I. Fleming in Comprehensive Organic Chemistry (Eds.: D. Barton, W. D. Ollis), Pergamon Press, Oxford, 1979, vol. 3, p. 541-686. ${ }_{[17 c]}$ H. Sakurai, Pure Appl. Chem. 1985, 57, 1759-1770.

${ }^{[18]}$ M. Patz, H. Mayr, Tetrahedron Lett. 1993, 34, 3393-3396.

[19] [19a] M. T. Reetz, Angew. Chem. 1982, 94, 97-109; Angew. Chem. Int. Ed. Engl. 1982, 21, 96-108. - [19b] T. Mukaiyama, Org. React. (N.Y.) 1982, 28, 203-331. - ${ }^{[19 c]}$ T. Mukaiyama, M. Murakami, Synthesis 1987, 1043-1054.

[20] [20a] D. N. Kursanov, Z. N. Parnes, N. M. Loim, Synthesis 1974, 633-651. - ${ }^{[20 \mathrm{~b}]}$ S. Pawlenko in Houben-Weyl, Methoden der Organischen Chemie 4th ed., Georg Thieme Verlag, Stuttgart, 1980, vol. XIII/5, pp. 350-361.

[21] H. Mayr, R. Schneider, C. Schade, J. Bartl, R. Bederke, J. Am. Chem. Soc. 1990, 112, 4446-4454.

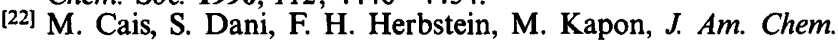
Soc. 1978, 100, 5554-5558.

[23] U. Behrens, J. Organomet. Chem. 1979, 182, 89-98.

${ }^{[24]}$ G. A. Olah, P. W. Westerman, D. A. Forsyth, J. Am. Chem. Soc. 1975, 97, 3419-3427.

[25] H. Mayr, R. Schneider, U. Grabis, J. Am. Chem. Soc. 1990 , $112,4460-4467$.

[26] K. Schlögl, Monatsh. Chem. 1957, 88, 601-621.

[27] F. S. Arimoto, A. C. Haven, J. Am. Chem. Soc. 1955, 77, 6295-6297.

[28] J. T. Suh (Colgate Palmolive Co.), U.S. Patent 3,415,859, 1968; Chem. Abstr. 1969, 70, 78158x.

${ }^{[29]}$ M. Rausch, M. Vogel, H. Rosenberg, J. Org. Chem. 1957, 22, 903-906.

${ }^{[30]}$ R. L. Schaaf, J. Org. Chem. 1962, 27, 107-111.

[31] M. Cais, A. Eisenstadt, J. Org. Chem. 1965, 30, 1148-1154.

${ }^{[32]}$ H. Mayr, W. Striepe, J. Org. Chem. 1985, 50, 2995-2998.

[33] Y. N. Polivin, V. N. Postnov, V. A. Sazonova, D. V. Zagorevsky, Y. S. Nekrasov, A. P. Kharchevnikov, J. Organomet. Chem. 1985, 288, 201-206.

[34] M. T. Reetz, M. Sauerwald, J. Organomet. Chem. 1987, 328, $155-160$.

[35] [35a] A. N. Nesmeianov, E. G. Perevalova, L. S. Shilovtseva, Z. A. Beinoravichute, Dokl. Chem. (Engl. Transl.) 1958, 521-522. - ${ }^{[35 b]}$ D. W. Slocum, W. E. Jones, C. R. Ernst, J. Org. Chem. 1972, 37, 4278-4281

[36] [36a] S. P. Gubin, E. G. Perevalova, Dokl. Chem. (Engl. Transl.) 1962, 346-349. - [366] N. S. Nametkin, V. D. Tyurin, S. P. Gubin, S. A. Smirnova, Dokl. Chem. (Engl. Transl.) 1969, $342-345$.

$[247 / 94$ 